\title{
Constitution Vis-A-Vis Constitution Indonesian 1945 Versus Papuan
}

\section{9}

\author{
Don A. L. Flassy ${ }^{1}$ \\ ${ }^{1}$ Prof. e.r. PhD, Papua Institute for Science and Technology/LIPTEK-Papua, Cenderawasih University/UNCEN \\ Correspondence:Don A. L. Flassy, Papua Institute for Science and Technology/LIPTEK-Papua, Cenderawasih \\ University/UNCEN, Indonesia.
}

Received: May 19, 2019; Accepted: June 6, 2019; Published: June 24, 2019

\begin{abstract}
Commonly, as it is shown, conflict is emerge among Tolerancemerger of Unity in Diversity versus Solidarity merger of Togetherness in Diversity as poles of spanning the natural and engineering efforts which are not natural to make or maintain existing fused together. The statement is welded by the spirit of Indonesia's 1945 Constitution versus Papua's1999 Constitution in the feasibility (practice) and philosophical (ideology) of Papua-Melanesian living in and integrated to Indonesia.

Regardingly, this article is therefore titled "Constitution vis-à-vis Constitution: Indonesia 1945 versus Papua 1999" intended to demonstrate the existence of each of the philosophical as well as the feasibility of correlation between the two as cause and effect in supporting the blare political action which is: "The Roadmap to the Revival of the Papuan Nation in West Papua: "A Peaceful Decision on the Restoration of the Self". Affair have been taken, namely through the Third Papua People's Congress (Kongres Rakyat Papua Tiga/KRP-3), October 16-19, 2011, where the Nation of Papua has announced Unilateral Declaration of Independence of the Nation of West Papua/UDI-Papua and formation of The Federal Republic of West Papua/FRPB (Negara Republik Federal Papua Barat/NRFPB) back to and continuing the Political Status of December $27^{\text {nd }} 1949$ to December $1^{\text {st }}, 1961$ (after Round Table Conference/RTC of The Hague to Political Manifesto of Papua). This is the status before Papua being occupied by and integrated within Indonesia at change of International conspiracy.

Thus, as well as to formulate the two basics: First, how to understand the presence of Papua-Melanesian inhabiting Land of Papua? Second, whether, People of Papua-Melanesian and Indonesia who inhabiting Land of Papua can being together according to the federalist order of Papua-Melanesian? This may also potentially for other basic formulation of discussion likely to reveal a back-rock (the unshakeable basis) of each of the existence which is of Papua and of Indonesia as two different nations. The two nations are, as being correlated in the process of time and idealism. The appearance of actual and accurate Papua in Indonesia because of the synergies and mechanisms of critically adhesives of interest to tolerate in corporation of national unity or Multiple-wide but One, but also at the same time hard spanned cohesive because there is no solidarity which is Togetherness in Diversity because the nature of rejecting merger.

There are many hidden presence but there are also some blatant. For this reason hidden structure theory needs to be implementing which convergent with other theories in the phenomenology-behaviourism methodology with the support of literature and empirical studies in practice (auto-ethnography).

Thus it can be understood that there is tolerance merger of Unity in Diversity versus solidarity of Togetherness in Diversity which for Papua-Melanesian living in Indonesia may reflecting any kinds of multiple singularities (a.o, the feeling of dual citizen, etc.). These ere poles of spanning the natural and engineering efforts (not natural) to maintain existing fused together. The controversial is reflected when matching constitution of the two nations i.e. 1945 Constitution of Indonesia versus 1999 Constitution of Papua.
\end{abstract}

Keyword: Papua and Indonesia, solidarity in togetherness versus tolerance in unity

\section{Introduction}

What is here become, the fundamental view is, the presence of Papuans as integrated element within the State and the Nation of Indonesia apparently still implies various disagree (Note 1), then the effort to uncover, was always seen as opposition or challenger and even as an attempt to act of unlawful alias in the formulation of the term 
'makar (treason)' or 'haatzaiartikelen'(sowing hatred articles), which is a Dutch colonial understand that not to be hated even stroked as a weapon of frightening.

Theory to be used in this study is Hidden Structure and Structuralism converged with other supporting theories, bringing the compromise and action to managed conflict discovered here between natures of diversity in togetherness versus natures of diversity in unity. The study then exploring method of library study as well as empirical (auto-ethnography). The practical purpose with respect to that is to know the concept of PapuaMelanesian related to the existence of daily life behaviour as well as philosophy in the form of "source of life" and "way of life". By employing structure linkage methods, among others: correlation method and comparison method or will be more wrapped up with the phenomenology-behaviouristic method to find and emerge to the surface as well as by approaching the auto-ethnographic method of self in order to clarify the position of the problem and consciousness of existences.

As shown above, the different standard may caused stigma which limiting the maturity of thinking public good on both sides namely of Jakarta in this case the Government of Indonesia in the broad sense and the Papuans themselves as the party to be integrated. In the sense of liberation, would like Papua from the Dutch, scholars in Indonesia (Papua) as if to see that Papuans themselves just being passive, waiting for the arrival of the "liberators" of the Indonesian territory west of the island of Papua. This is reflected in the words that "Indonesia "liberates" the Papuans" from Dutch colonial rule (see, for example, Lubis, 1984). The role of the Indonesian people (nonPapuans?) -Like Sam Ratulangie, Yos Sudarso, even Benny Murdani (Note 2) -in "liberating" or "educate the national consciousness" among "the Papuans," whether it is also exaggerated it?

George Junus Aditjondro (1993) calls the pattern of acceptance and understanding such as fraud of Papuans Nationalismin Historiography of Indonesia. Of the various clashes opinion of Jakarta as the party that presents a policy is not the slightest pursue policies that are not wise (policy of non-virtue) put Papuans who integrated as the party of never stopped demanding forth, both to and from the inside and ignited by the international.

Events and series of political occurrences in Papua, known as the roar of the transformation is complete on the tracks of the Indonesian Reformat the end of $20^{\text {th }}$ century of (1997-2000) then all obsolete form of resistance guerrilla performances witch into forms of dignity diplomacy. At that time, in 1999, the Papua Independent Committee (Komite Independent Papua/KIP) also just formed in 1988, commissioned by the Leader of Papua Theys Hio Eluay (Note 3) follow-up work which is not completed designed by Papua National Committee in 1961 that is set on October 19, 1961 in the form of the Political Manifesto of Papuans in West Papua which was declared on December 1, 1961.

Similarly, the Basic Guidelines of Papua Melanesia was launched with typical charge of Triple Fold Logic of Melanesian-Papuans in the Malay and English version was held into the Basic Guidelines-Triple Fold Logics of Melanesia-Papua.(Note 4) This academic intellectual work is intended to support the efforts of mass mobilization that culminated in three major events after the appearance of 100 Team (Tim Seratus) Delegation of Papua in February 6, 1999 for National Dialogue on coordination of Reconciliation Forum of People of Irian Jaya (Forum Rekonsiliasi Rakyat Irian Jaya/FORERI) with the President of the Republic of Indonesia, Professor B.J. Habibie. The 3rd Indonesian President was although mention the act of the Papuans through the 100 team as " $a$ soft rebellion" at the same time advised to "pulang dan renungkan kembali (go home and think back)". Here then after reflecting on the fact (Note 5) there was a backlash among Papuans in the form of three events in a row respectively: The rising of National Flag of Papua the 'Morning Star' alongside Indonesian National Flag 'Two Colors' in December 1, 1999, with the demands of Reset the Name Papua, Align History of Papua, and Held The Extraordinary Papua National Ensemble (Musyawarah Besar/MUBES Papua) on February 26, 2000 revised the West Irian Congress in the Act of DMP-PEPERA 1969, and launching National Congress of Papua to Declaring Transitional Government of Papua.

The MUBES Papua took place on February 29, 1999, and then the Second Papua National Congress took place on May 29 to June 3, 2000 in follow up the First Papua National Congress in 1961 by Papua National Committee (Komite Nasional Papua/KNP) notching by New Guinea Council (Nieuw Guinea Raad/NGR), made-up Political Manifesto of Papuans in West Papua.

This is originated from the desire to reproduce the Deliverables of First Papua National Congress that is, the Basic Guidelines with Triple Fold Logic of Melanesian-Papua held in the format of the Charter and Constitution of Papuans. This document is very limited indeed, circulate only in the National Congress that despite appearing in public through the mass media that reported by the Weekly Tifa Irian, the second week of May 2000 for a limited Papua and world wide by Agency of France Press, June 6, 2000. 
Because the mechanisms and design elements that bad image diverting The Second Papua National Congress was rather complement the First Papua National Congress with Constitution and Declaration of Government instead the Leaders, Theys Hio Eluay and Thom Beanal led to negate the original purpose of the Congress which is to declare the Transitional Government of Papua become "received Special Autonomy (Otonomi Khusus/OTSUS), replace merdeka (independence)". On condition beyond a doubt that the manuscript of the Papua Nation Constitution1999 to be valid and became hampered as well as the Manuscript of Transitional Government.

However, by a researcher of Van Vollenhoven Institute for Law-State University of Leiden (which for some reasons was not mentioned by name) had commented academically against this text as"Constitution on the boundary-line of periphery-marginal of the State of Indonesia". Although it may be a taboo to reveal the back but felt the need to be known to sit because as an intellectual product of academic effort direct correlation with the Constitution of the Republic of Indonesia1945 (if Papuais in the integration) that shadow Constitution of Papua (if Papua is outside integration).

Although the manuscript was received, then was passed onto the Third Papuan National Congress (KRP-3) 16-19 October 2011 as material on congressional provisions.

\section{Problematics}

This study needs to reposition whether the interests of the Papuans, (call: Papua Nation) that has been accommodated in the Indonesian constitution in accommodative manner or justin performance alias occupied which obligatory submissive and obedient to that occupier by other words integrated submissive and obedient to the perpetrators of integration or integrator. This is where the term 'invaders' or 'colonial' or 'imperialism' to be tested.

While on the other hand Papua(as an integrated nation) is not always true, because the opportunity to define them as independent may occur (outside the integrator nation). As has been lit revealed, at least four episodes of wasted namely the First Papua National Congress initiated by the Papua National Committee formed by the Nieuw Guinea Raad (Papua Council) when it launched a Government of Papua as alleged by the President Soekarno in The Tri Command of People: 'Disband the Puppet State of Papua made by the Netherlands in West Irian home land of Indonesia' while the Papua just on stage to talk about the completeness of the State in the form of State Emblem Bird Mambruk pigeon (Gaura Victoria Regiapapuana) and Papuan flag Morning Star and the National Anthem of West Papua 'Hai Tanahkoe Papoea' completed the name of the Nation as "Papoea Nations" and the country name of "Papoea Courant West".

So first be preceded by a declaration to be Papua Volks (Nation of Papua) and the country name of West Papua. Although at that time there already a manuscript which was compiled intellectually by a member of the Papua National Committee who also member of Nieuw Guinea Raad, Nicolaas Tanggahma the representatives of Fakfak electoral districts.

The following opportunities occur in the Act of PEPERA in 1969 that at that time there were only voice that of Eduard Hegemur (Note 6) again from Fakfak electoral districts requiring the Free Papua became State's of own outside any country both Indonesia and the Netherlands. One only truth was among 1026 voices of lies. This incident with various other motions of the Papuans themselves as well as for the support of 30 Member States of UN supporting the proposal of Ghana,(Note 7) now only decorates the archives of the United Nations simply by the word 'take-note' (bubbled by Security Council of the United Nations 19 November 1969).

The third occasion occurs during the National Dialogue 100 Team to meet with President Habibie, instead "the independence" must declared first then report, the action was to ask for Indonesia to give. Obviously it was rejected with the words "pulang dan renungkan kembali (go home and think back/look at your self at the mirror)" however the word "soft rebellion" was expressed by the $3^{\text {rd }}$ President of Indonesia in commenting the request submitted by the Papuan 100 Team.

The fourth opportunity was occur in and on the rails of Indonesia Reform to obtain the grace and ease of the Government of Indonesia through Kiai Haji Abdurahman Wahid famous with Gus Dur, the $4^{\text {th }}$ President of Indonesia, is to allow the raising of Papua Flag, returning the name of Papua replace the stigmatizes backwardness and enslavement name of Irian (Barat or Jaya) and the all-important of all of them, allowing the Second Papua National Congress be organized by sponsoring a fund of 1 billion rupiah.

Papuan people apparently do not see this as an opportunity to complete the tasks of the First National Congress of Papua which still incomplete i.e. by announcing Transitional Government, though the chance of that is very promising. Including in this case did not ratify the Constitution (the one in charge of Basic Guide Lines and Triple Fold Logic intended). 
The re-studies be categorized "rectification step" of Papua's history(Note 8) according to the mandate of Article 43, 44, 45 and 46 of RI-Law 21 of 2001 on Special Autonomy for Papua Province, presumably a proposal submitted as a measure of participation of individuals in order to provide input to the Order of Formal governance attendance.

In that regard, returned comments by the researcher of Vollenhoven Law Institute, it is, the manuscript in question is the involvement of cultural creativity framed in correlation with the Constitution of the Republic of Indonesia, Papua customs and specific cosmopolitan (universalism). The resulting manuscript virtually an image of very broad and spacious even be read as a hyper-rationalism with charisma, creativity and structure, generating from foundationalism proposed, and inspired by unrest, demonstrating the way of life (principles of life). Not the same as the traditions constitutional in the west that is the constitution moves by self-constitution (outside charismatic stage) and become routine as the bedrock foundation of law (unshakeable law).

The Constitution meant here again following the researcher of Vollenhoven Law Institute, is still warm and can be disturbed. That is there for should be read as an astute reflection on the current condition and use of the potential for the state to use a reference mixture of lectures, ideas and different political systems.

The leading is a response to the instability of government in Papua, which was introduced by an ever-widening gap (distance immortality span) between legal certainty and achievement granted by principal of national unity in tolerance (Indonesia) versus national diversity in solidarity (Melanesian-Papua).

\section{Flows of Mandate}

Gaining the further highlight from the researcher of Vollenhoven Law Institute, to explain the specific charge of Basic Guidelines-Triple Fold Logic of Melanesian-Papua is indeed possible to show how the current mandate opposing surrounds the idea of a new nation with a constitution built on an understanding of the Indonesian state, with borrowings from performance to domestic Christianity and legality assurance of heritage (customs) revitalized of Papuans continue to increase in light of the political shock conditions of the Nation and State of Indonesia. Certain contextual influences on the constitution also includes knowledge of the Dutch colonial government and the ownership understanding of sources and idiosyncratic knowledge of New Guinea stored in the collection of Netherlands and other intimacy. From a more regional level, there is also the influence of Melanesian eschatology to generalize and idealize the notion of culture and customs (environment) of the Papua Nation. Must be respected certain environment where include audience-in-mind (attention-in-thought) to understand what is going on.

Basic Guidelines-Triple Fold Logic Melanesian-Papua is a product of the cosmopolitan periphery of Indonesia so is a sign of engagement of local traditions with global magnitude laid Papua in a vast world.

The Constitution was written by using various sources of neighborhoods near Jerusalem in the land of Judah, NewYork on American soil, and others including Betawi Jakarta in Indonesia and of course the Netherlands that is so is a global format cosmopolitan engagement. The engagement took place in imbalance of strength (power) between the centers of the country with the outer boundary (the periphery). Writing a constitution is among them out powerful practice to lay it bare (what ever they are), deconstruct (de-tightens) and redefine the boundaries of race and culture in the StateIndonesia versus Papua.

No constitutionalism that match this constitution that arranged marginal on-line or line-edge of the Country presumably so the response of the audience could possibly happen. Field as it will be seen on the conditions by which this base and the foundations of the sacred (taboo and divine) for the laid of an alternative state.

The Constitution is the fruit of work that virtually creative and sophisticated possessing a clear vision. The source or basis of inspiration or holygrails (holy innuendo) (Note 9) variety and method of composition is very colored various broad in sight while the goal is obviously to generate a structure that will abdicate those who have too much power and inherited rights for all, including supposed to protect the rights of the marginalized (in the sense, too, including those who are integrated).

Dependence on the dissemination and response, social processes may lead to coverage of the mobilization of the Papua People's intention "M" of their own or against the opinion desired but also a kind of interaction is presented by people in Jakarta.

The latter possibility will always exist around the corner but it is often not recorded by Jakarta. (The Book of) Sinkronisasi (Synchronization) written by this author (Flassy, 2004) (Note 10), the said is an event that clearly would a foundation for creative reciprocal agreements between center and periphery countries and governments of the region which often causes a reaction very stiff and scary (virtue unwise and or policies that sometimes noncivilized) from Jakarta. However, as shown by Timmer (2004, 2005), gap between Jakarta and Papua is not 
narrowed, it is also, perhaps the central and periphery boundary most east of the country to each other are involved when educable entities (unity of learning) so that the two are closely related to each other in the understanding of balance, of the price-appreciate the value, and of cosmopolitan connections of cultural traditions and knowledge.

An other defense is knowledge and wisdom of local domestic (emics), which is almost always stagnant when introduced outside knowledge (ethics) which followed in the construction of the still underlying prejudices and assumptions omniscient will target service (Papua as a target group).(Note 11)

\section{Different in the Unity}

In this case, which of course is not easy to be come part of the establishment or obtaining point to be accommodated in to repertoire consideration the concept of the Republic of Indonesia: Bhineka Tunggal Ika (Diversity in Unity)? As has been revealed before, as derived from the basic philosophy of Tri Fold Logic of Melanesia-Papua is an entirely different question remains distinct or Unity in Diversities. In a sense, each element not smelt (intact no yield) mosaic banded (integrated in mosaic) then it is completely different and it is still different, that of the respective interests of balanced manner cybernetic(synergy) as solidarity, togetherness, customs and attitudes, including the interest of both the race of Papua is Melanesia and humanity in another scale, especially in the integrity of the Republic of Indonesia (NKRI) can certainly be tested.

Then in the understanding of the 1945 Constitution of the Republic of Indonesia with Pancasila and the 1999 Constitution of Federal State of Papua with Melanesian-Papua Triple Fold Logic at the edge of periphery or marginal line of the Republic of Indonesia was to be paired academically and intellectually. With the aim to draw from both crosses smart for both parties in the advancement of mutual understanding and mutually beneficial multilaterally. In this regard the Government of Indonesia to seek the flexibility of the immortality of government behavior (integrator) which is in entering the feel of Papua(integrated parties) in the balance of dignity and fulfill the values of civilized humanity.

The existence of an understanding of the constitution in marginal line and periphery boundary is, the possibility of judicial review and even test of the quality of what is meant by local wisdom (local knowledge) nations and tribes in the Republic of Indonesia (read: Nusantara/Archipelago) was has accommodated perfectly in Pancasila and the Constitution of 1945. Call it "Shari'ah-Islam", which is said to be excluded from the Preamble of the Constitution of 1945, but remained local wisdom intentions for the people, regions, populism and certain ethnic groups. That State Idealism of Indonesia starting from Syarikat Islam then row of three Indonesian Islam nationalist, whom were, Tan Malaka, Sukarno and Mohammad Hatta launched their writings as shown by Yos Rizal Suriaji (2008). The figure of Tan Malaka was the first to initiate written concept of the Republic of Indonesia. He wrote Naar de Republic of Indonesia (Towards the Republic of Indonesia) in 1925, much earlier than Mohammad Hatta, who wrote Indonesia Vrije (Indonesia Merdeka/An Independence Indonesia) as a plea before a Dutch court in The Hague in 1928, and Bung Karno, who wrote Menuju Indonesia Merdeka (Toward An Independence Indonesia) in 1933.

Indicates Islam as a milestone of Indonesia or virtually Pancasila and Shari'a as two sides of one coin that will not actually be enshrined absence only (read: Preamble UUD'45) because it would have appeared also in the policies of all Regional Regulation (Perda, Perdasus, Perdasi) even though RI Act, in the later period (Note 12). Islamic law is thus back rock (unshaken) and inner-deep structure (or backbone) which is hidden structure of UUD'45. The original formulation of the manuscript of the Jakarta Charter reads: "... based on: the deity, with the obligation to carry out the Shari'ah for adherents, according to the basis of just and civilized humanity, the unity of Indonesia, democracy, led by the inner wisdom of deliberations representative and by fostering a social justice for all Indonesian people".

From this point any way, this author wishes to reconcile the Constitution of the Republic of Indonesia UU'45 with the text of the constitution of boundary-line or marginal periphery of the country of Indonesia. The imagination is on the Constitution of Federal State of West Papua with the Melanesian-Papua Tri Fold Logic. The first mentioned as already discussed above insightful of pyramidal syncretism of Islamic Nationalist minded while the latter is balance mosaics of Christianity and Customs of the Melanesian-Papua. In a sense not intended to oppose but rather look for entry points that allow acceptance of differences and similarities between the cosmopolitan as intelligent wisdom in order to get a balanced solution between the parties.(Note 13)

The 1999Constitutionscript was based on 3 previous scripts that are Pulau Fajar Keemasan: Sebuah Anjuran Kerjasama antar Negara dan Pemerintahan Transisi Papua Barat (Golden Dawn Island: A Cooperation Exhortation between States and the Transitional Government of West Papua) by Papua Independent Committee (Komite Independent Papua/KIP), Port Numbay April 1999 and Rendevous dengan Perjuangan Kemerdekaan Papua Barat (Rendevous with the Freedom struggle of West Papua) in 1999 and two more are Pedoman Dasar 
Bangsa Papua 1999 (Basic Guidelines of Papuan)1999 and Draft Konstitusi Negara Federalis Papua (Constitution Draft of Federal State of Papua) in 1999.

Referred to the first book was been thought if the Government of Indonesia and the people of West Papua reach an agreement in the dialogue as well as the Round Table Conference as held in The Hague1949 to position the Sovereignty State of the Republic of Indonesia, then all defense cooperation, including economic and labor citizenship can negotiate intended as advised. The second manuscript is an admiration for what the accomplished writer of Papuans after integration while fighting for their existence in uncertainty and yet can be realized as far as this limit.

Furthermore the script of 1999 Constitution referred to, can be seen in the context of fulfilling the criteria: theterritory, the people, the willingness, then the country and it is necessary for the rules, so the constitution is positioned at the periphery boundary and marginal line to the 1945 Constitution, in the sense of a reality correlated with a shadow.

From another angle as well as this factual is about to be answered DjuyotoSuntani, 2015,"Indonesia to be Broken". The book with a straight forward and arbitrary style of Javanese by typical style of knowing-all(or quasi-know) showing the conquest as eternity. This is where the mistake. Papua, which in Indonesian great personalities minds and also of the all great people do not positioned as Region, Human and Civilization were awakened ten years (1949/1950-1960/1961) separate from the Dutch East Indies which is different than the others.(Note 14) Not just a district or a region of the Sultanate of Tidore which of not at all any progress and at all no balanced. Howone cans could equate Hollandia 1955 for example withTernate in the same year which is still a villages and hillbilly. Else, if Djujoto Suntani said like that, then Papua is not included inthe said anti-Christ.

\section{The Juxtaposing among the (Reality) Constitution of the Republic of Indonesia to the (Shadow) Constitution of the Federalist State of Papua}

The Juxtaposing among both constitutions thus can be discussed and given outlook as follows:

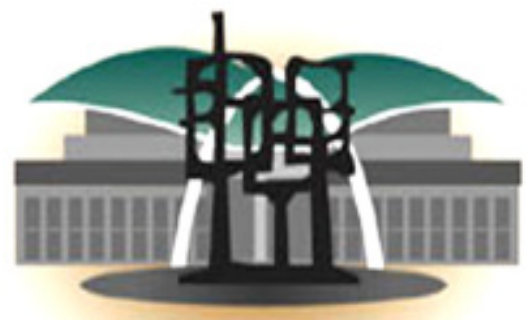

Figure 1.

\subsection{The State Basings of the Republic of Indonesia}

\subsubsection{The Constitution 1945}

The Constitution 1945 or Undang-Undang Dasar (usually referred to as UUD '45) was written when Indonesia was emerging from Japanese control following World War II, and declaring its independence from its former colonial occupier, the Netherlands.

The Constitution was abrogated by the Federal Constitution on 27 December 1949, replaced by the Provisional Constitution on 17 August 1950, and restored on 5 July 1959, experiencing the followings:

- Today, the Constitution is the supreme legal authority and requires the deference of all governmental actors in the State of Republic of Indonesia. Since 1999, amendments to the Constitution have increased its size from 37 articles to 73 articles. This version of the 1945 Constitution has been annotated by the Department of Information, and the English translation is only provisional.

- The following provisions of the 1945 Constitution are potential sources of intellectual property rights: Article 32 (patents and copyright) and Article 33.3 (genetic resources).

As juxtaposing to the Constitution of 1999 the author was based on the original script before the amendment so that it appears there is a correlation, but there is also another step forward regarding the natural environment, human rights, ownership of private armed and others that do not appear in the original of 1945 but then appear in the amendments text. 
The other thing which is also recorded in 1945is, among others: Here the State border of the point of coordinates or the place name is not mentioned, what is not a deliberate way? Necessary inputs to improve the amendment. Also that since 2009 for the first time by the Direct Election of People was held in Indonesia.

Included in this correlation the State Bodies which have been omitted in the text of Amendment of UUD 1945 was still visible on the Constitution of 1999, of which the Badan Pertimbangan Agung (Supreme Advisory Council)/BPAand the election by the Majelis Permusyawaratan Rakyat (Assembly)/MPR .

The full text can be seen on the original manuscript tof the Constitution of the Republic of Indonesia Year 1945 by National Law Development Agency, Ministry of Justice and Human Rights in 1998 where for the Amendment manuscript can be seen in the Development Reform Cabinet MPR Decree No.1998-2003II/MPR/1998.

\subsubsection{The Attribution of Republic State of Indonesia}

\subsubsection{Symbol of the State of Indonesia "GARUDA PANCA SILA"}

As previously mentioned, the UUD'45 was digging out from the fundamental philosophy of principals in Panca Sila shown by symbols at the chest of Garuda.

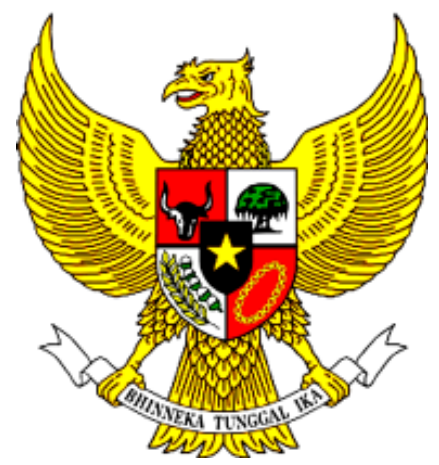

Figure 2. Garuda Pancasila, State Weapon of the Republic of Indonesia

\subsubsection{Pancasila}

The affirmation and or understanding of each Sila (principle) https://id.wikipedia. org/wiki/Pancasila broadly stated as follows:

Sila number 1: One supreme God asserted that the people of the nation of Indonesia believe God exists. It also implies that the people of the nation of Indonesia believe there is life after death. It is emphasized that the teaching and holly values will lead the people of Indonesia to a better life in the hereafter. This principle is based on the belief that there is only one God that is God Almighty symbolized by the star in the center of shield of Garuda Pancasila.

Sila number 2: Humanity of Fair and Civilized stated that there is the human desire to be treated with respect and concern for the dignity they deserve as creatures of God. In a sense emphasizing that the people of Indonesia do not want the pressure of physical or spiritual people by the people of its own nation as well as by other nations. This spirit is symbolized by a chain displayed at the bottom right of the shield indicates that the generation of the human race in succession comply with this spirit.

Sila number 3: Unity of Indonesia, confirmed the existence of a form of the concept of nationalism, of a resident person of Indonesia nation people love the country and nation by considering the need to always foster integrity and national unity. Pancasila nationalism demands that every citizen of Indonesia to avoid feeling superiority on the basis of an ethnically pure, consideration of family lines and color as stated in Soempah Pemoeda (Youth Swear) 1928: Satoe Toempah Darah (One Homeland) Indonesia, Satoe Bangsa (One Nations) Indonesia, Satoe Bahasa (One Languages) Indonesia immortalized with the motto "unity in Diversity" which means diversity in unity, symbolized in banyan tree on the top right of the shield.

Sila number 4: Populist Led by Wisdom in Consultative/Representative, expressed on democracy of Pancasila that requires decision making through a process of musyawarah (deliberation) to reach consensus or agreement. This is characteristic of vibrant democracy and principle of Pancasila. This fact implies that the right or the truth of a democratic must always be tested with a feeling or sense of responsibility to God Almighty according to the sentence which demands self and religious faith, with respect for the values of humane about the integrity and 
dignity of human beings and with a view to maintaining and strengthening national unity and justice, symbolized by the Head of the Wild Bull on the top left of the shield.

Sila number 5: Social justice for the whole people of Indonesia, requires dissemination and equitable prosperity hat deserves to all residents and citizens or not static but progressive and dynamic. In the sense that all the country's natural resources and the national potentials should be used as best as possible evenly to the happiness of the citizens of the nation. This justice implies protection of the weak by providing employment opportunities in the field and ability of each person. Protection is required to prevent arbitrary actions of the strong and ensure the rules of justice to the meaning of this, as symbolized by Rice and Cotton grains on the bottom left side of the shield.

\subsubsection{Symbol of Garuda}

The symbol of garuda (https://id.wikipedia.org/wiki/Lambang_ Negara_Indonesia) was in adjacent to the real hawk eagle. This bird is found in the paintings in temples of Dieng described as beaked and winged man, then at Prambanan temple, and Panataran shaped like a giant, beak, claws and long haired. Some kingdoms in Java had used Garuda as the stamp/royal seal, as is stored in the National Museum, is a stamp owned by the Kingdom of Erlangga (sultan_abdul_hamid2-01). Garuda established as the State Emblem of Indonesia since inaugurated on February 11, 1950, and set forth in Government Regulation No.66 of 1951. Initiator was Sultan Abdurrahman Hamid Alkadrie II, known as Sultan Hamid II, who then served as State Minister of the Negara Republik Indonesia Serikat (United States of Republic of Indonesia/RIS).

In Hindu mythology this bird appears with the name Jatayu as rescuers of Dewi Shinta the lover of Rama from the giant Ravana. While on the other hand, this bird is also said to be Buraque that was bird creature driven by the Prophet Muhammad to heaven on Isra Miraaj. In character, Soekarno merged these two forces (Islam and Hinduism) to unite Indonesia.

What we may know of among some Papuans, especially from Kaimana to Sorong and throughout the Bird's Head Peninsula is on this bird will also sound another. That Soekarno when discarded by the Dutch became internment in prison of Boven Digoel, has come out to Lobo in the south of Kaimana and took the power of the bird along with a keris from the mountain Nabi (Prophet) among Fakfak, Bintuni, Babo, Kaimana and Wasior. That strength has been brought to Batavia and became power of Indonesia as a country. Although we do know very well, that Sukarno was discarded by the Dutch but not to Boven Digoel as so far to the east just to the Ende-Flores where the rest in Sumatra and Java. That was to Boven Digoel only other fighters, among them Mohammad Hatta and Sutan Sjahrir. And the keris was just a private property of Soekarno which not belong to the royal or government forwarded. Not from Suharto nor Yudhoyono turned out without any kind of keris and neither Joko Widodo who is the 7nd President now (2014-2020) and whose ever in the future.

\subsubsection{National Flag of the State of Republic of Indonesia "DWI WARNA"}

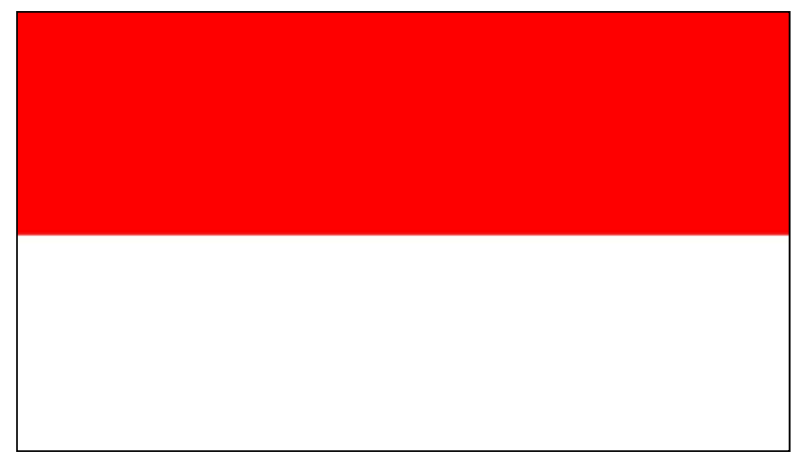

Figure 3. Dwi Warna The Flag of the State of Indonesia

\section{1) Origin}

The flag of the Republic of Indonesia, the Red and White (https: //id.wikipedia.Org/wiki/Bendera_Indonesia) in Sanskrit marked into Dwi Warna (Two Colors), is a simple flag with a two-color design that is divided into two sections horizontally (landscape). The color was taken from the color of the Majapahit Kingdom. Actually, not only the kingdom of Majapahit wore red and white flag as symbol of greatness. Before Majapahit kingdom of Kediri had wearing red and white pennants. 
In addition, the war flag of Sisingamangaraja IX from Batak was wearing a red and white as the color of its flag, pictorial twin swords white color with red and white base. Red and white is the color of the flag of war Sisingamangaraja XII. Two twin swords symbolized piso gaja dompak (densely packed), heritage of kings of Singamangaraja I-XII.

When the war in Aceh, the fighters of Aceh had used the flag of war in the form of banners in red and white, on the back applied swords, a crescent moon, sun, and stars and some verses of the Quran.

In the age of empire Bugis Bone, South Celebes before Arung Palakka (rafting), the flag of Red and White, was a symbol of power and greatness of the kingdom of Bone under the famous name of Woromporang.

At the time of the Java War (1825-1830AD) Pangeran Diponegoro wear pennants of red and white in its struggle against the Dutch.

The flag, called the Sang Merah Putih (Red and White) was first used by students and nationalists in the early20th century during still under Dutch rule. After World War II ended, the independence of Indonesia had started using this flag as the national flag.

\section{2) Meanings and Colors}

Indonesian flag, Dwi Warna, has a philosophical meaning. Red means bold, white means holy. Red symbolizes the human body, while white symbolizes the human soul. Both are complementary and perfect for Indonesia.

In terms of history, since time immemorial both red and white contain sacred meaning. Red color is similar to the color of gula jawa (brown sugar/palm sugar) and white color similar to the color of the nasi (cooked rice). Both of these materials are the main ingredient in the cuisine of Indonesia, particularly in Java. When the Majapahit Empire triumphed in the Nusantara (archipelago), the color of the banner used was abang putih (red and white) banners (pennants red and white). Since the past red and white by the Javanese used for salvation ceremony of womb after four months age baby in the womb in the form of slurry which was given a red dye portion. The Javanese believe that pregnancy begins since the unification of red elements as symbols of the mother, the blood spilled when the baby is born, and the element of white as a symbol of the father, which is planted in the gua garba-senggama (womb of intercourse).

While, from our knowledge, the countries of the Middle East that breathe of Islam by understanding the red is the desert and white is a sword in proclaiming the truth of"Islam" to combat "kafir" (disbelief).

3) Regulations of the Red and White Flag

The Regulations on the flag of Red and White contained in:

1. UUD ' 45 article 35; the flag of the Indonesia State is Sang Merah Putih (The Red and White).

2. Government Regulation No.40/1958 on the National Flag of the Republic of Indonesia.

\section{4) Similarities of Red and White Flag}

From the knowledge of the flags of the nations that have similarities with the flag of the Republic of Indonesia, both by design and composition is different or similar but to the base is the same, the color is red and white. Can be shown as follows:

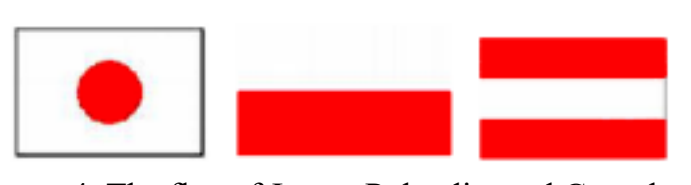

Figure 4. The flag of Japan, Polandia, and Greenland

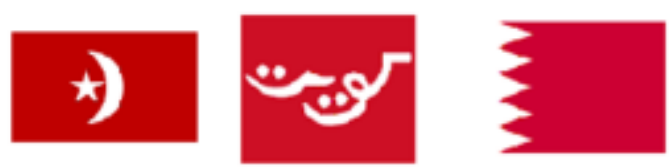

Figure 5. The flag of Arab Emirate Union, Kuwait 1915-1961, Bahrain 


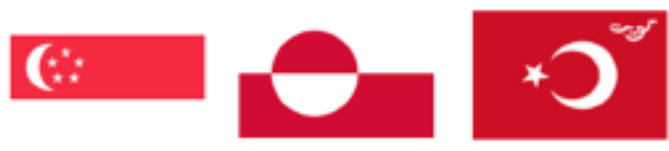

Figure 6.The flag of Singapore, Greenland, Kuwait 1909-1915

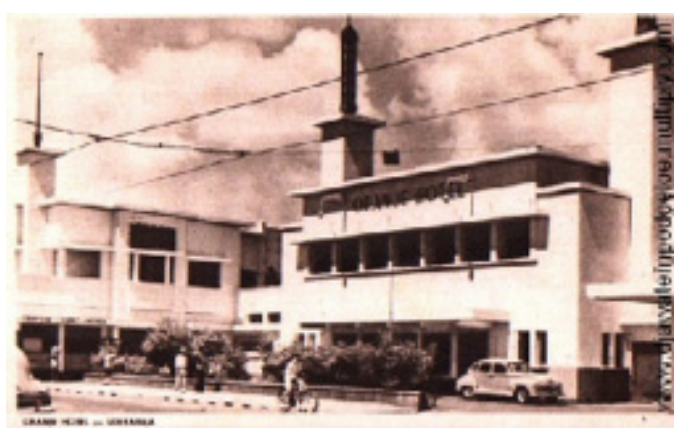

Figure 7. Oranje Hotel in Surabaya, was the place where the Dutch's tri-colour torn its blue became Dwiwarna of Indonesia

While there are also opinions evolve that are not based on strong references that besides influenced by the Japanese who ruled or occupied Indonesia ahead of the proclamation, also said to be the top and middle of the flag of the Netherlands(Red, White, Blue) torn its bottom when flown at Oranje Hotel in Surabaya and was rushed to Jakarta, in addition of course is designed of Sukarno and sewn by the lady Fatmawati before flown at the Proclamation in East Pegangsaan Central Jakarta.
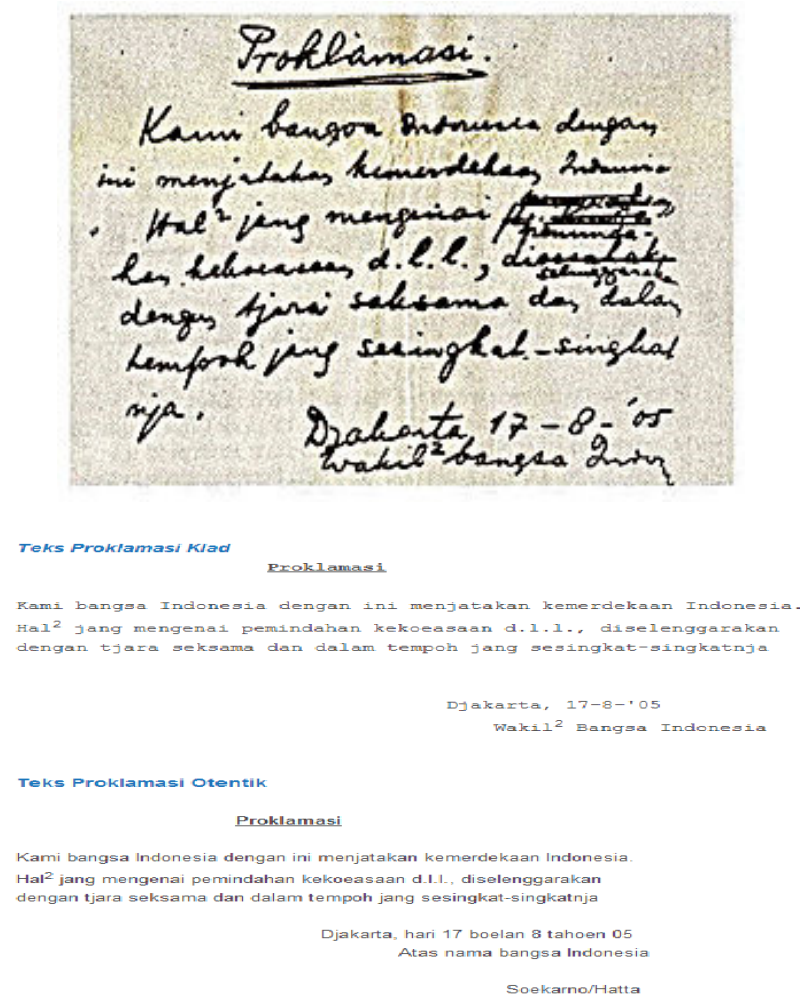

Figure 8. The copy Indonesia Independence Proclamation Text. 


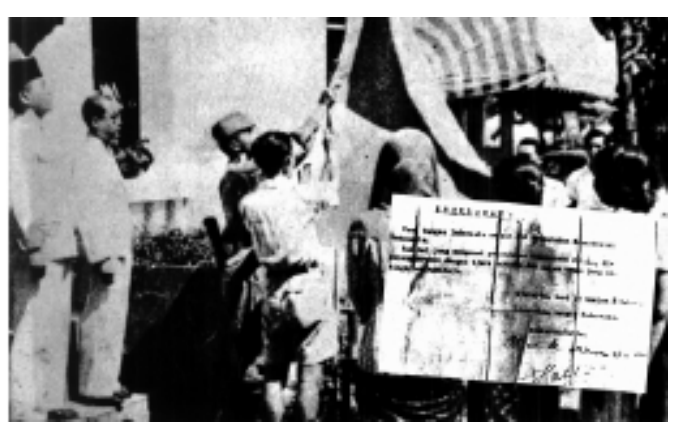

Figure 9. Soekarno and Hatta as well the audience watched the flaying of the origin flag at Pegangsaan Timur, Cental Jakarta: "After the echoud of Indonesia independence, 17-8-'45

\subsubsection{National Hymn of the Republic of Indonesia "INDONESIA RAYA"}

National Hymn or Anthem of Indonesia (https://en.wikipedia.org/wiki/ Indonesia_Raya), although it still continues to be suedas are plica of a Dutch arrangements for standardized of historical knowledge still held the opinion that it is the work of a son of Indonesia named Wage Rudolf Supratman. Here are the complete threestanzas of the national anthem the IndonesiaRaya:

\section{Bait 1:}

Indonesia tanah airku, Tanah tumpah darahku.

Disanalah aku berdiri, Jadi pandu ibuku.

Indonesia kebangsaanku, Bangsa dan Tanah Airku.

Marilah kita berseru "Indonesia bersatu."

Hiduplah tanahku, Hiduplah negriku,

Bangsaku, Rakyatku, semuanya.

Bangunlah jiwanya, Bangunlah badannya.

Untuk Indonesia Raya.

Refrein:

Indonesia Raya,

Merdeka, Merdeka

Tanahku, negriku yang kucinta.

Indonesia Raya,

Merdeka, Merdeka

Hiduplah Indonesia Raya.

Indonesia Raya,

Merdeka, Merdeka

Tanahku, negriku yang kucinta.

Indonesia Raya,

Merdeka, Merdeka

Hiduplah Indonesia Raya.

\section{Bait 2:}

Indonesia! Tanah yang mulia, Tanah kita yang kaya.

Di sanalah aku berada Untuk slama-lamanya.

Indonesia, Tanah pusaka, Pusaka Kita semuanya.

Marilah kita mendoa, "Indonesia bahagia!" 
Suburlah Tanahnya, Suburlah jiwanya,

Bangsanya, Rakyatnya semuanya.

Sadarlah hatinya, Sadarlah budinya.

Untuk Indonesia Raya.

Refrein:

Bait 3:

Indonesia! Tanah yang suci, Tanah kita yang sakti.

Disanalah aku berdiri menjaga ibu sejati.

Indonesia! Tanah berseri, Tanah yang aku sayangi.

Marilah kita berjanji: "Indonesia abadi!"

Slamatlah Rakyatnya, Slamatlah putranya,

Pulaunya, lautnya semuanya.

Majulah Negrinya, Majulah Pandunya.

Untuk Indonesia Raya.

Refrein:

Narrated (sources above), once upon a time, in a modest house in Central Gang of Salemba Jakarta, was born the song of Indonesia Raya from a young man named Wage Rudolf Supratman. The song recorded by TioTek Hong is played first in theYouth Congress in Jakarta in 1928. But this patriotic song then banned by the Dutch colonial government. The lyrics "merdeka (independent)" replaced with "mulia (noble)" so a bits oft. WR Soepratman other works is a roman cetitled Perawan Desa (Virgin of Village), seized by the Dutch colonial government. Roman is about land lords whou sed his fortune to have fun with the innocent village girls. The storyis considered to cause hatred between the factions.

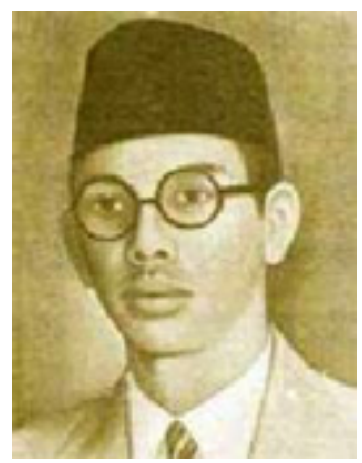

Figure 10. Wage Rudolf Soepratman, The Composer of Indonesia Raya

WRSoepratman's life is relatively short, but the34-year times span that passes carved his name as a hero. He is also known as a journalist and teacher. He has taught in Makassar after graduating from Klein Ambtenaar Examen (School for Small Employees) and school teachers of NormaalSchool (Normalized Teacher). In the world of journalism, he worked at newspapers KaoemMoeda, Bandung, then became editor in chief Kaoem Kita and establish AlphenaNewsjoint with P.Harahap, lasthe moved to ChineseMalay news paper SinPo as a freelance helpers.

INDONESIARAYA was in 1951 standardized at the initiative of Jusuf Ronodipuro, Head of Radio Republik Indonesia (RRI) Jakarta. Jusuf asked Jozef Cleber, a Dutchmusician, to compose the song. BungKarno agree.

This figure did exist but what is said about the song Indonesia Raya could simply engineering by Sukarno in order to make this tracing into something legitimate. According to the author this is no matter at all, because the strength of the song has becomea glorified is a legal product and the recognition of a nationas well as songs with metrum of Terang Bulan Terang Di Kali (Moon Light Bright into River), now became National Anthem of Malaysia as well as song "Hai Tanakoe Papoea (Oh, My Land Papua)" be PapuanNational Anthem. 
Further and complete account of the debate of Indonesian National Anthem "Indonesia Raya" can be seen in this author's bookwith the same title with this chapter, namely (2004) Constitutionvis-à-vis the Indonesian Constitution 1945 versus PapuaConstitution 1999, Jakarta, HAM.

\subsubsection{Indonesia-Soekarno-Islam}

Talking about Indonesia certainly can not be separated from leaders of Sukarno and Islam as state fundamental even though there is here and there coloredmixture especially also Jawi, slightlySanskrit Hindu, Christian and else. About all of it are indeed a lot of literatures that discussed at length.

The focus of the author in this case is lead to see Sukarno as a figure of people, prominent founder of Indonesia (https://id.wikipedia. org/wiki/ Soekarno). Dr.HC Ir. H. Soekarno, name of born Koesno Sosrodihardjo, born in Surabaya, East Java, 6 June1901 - died in Jakarta, 21 June1970 (69 years) was the first president of Indonesia who served in the period 1945 to 1966 . He played a key role in liberating the people of Indonesia from Dutch colonial rule. He was proclaimed the independence of Indonesia (along withMohammad Hatta) that occurred on August 17, 1945. Sukarno was first sparked the concept of Pancasila as the state foundation of Indonesia and he himself called it.

Soekarno bearing background and is well understood by Islam (in this case the people and the ulama (clergy) son then not doubt of ideas, ideology of Indonesia in this regard Pancasila as the State Fundamental, the UUD 1945 (Constitution) as the embodiment, of course, still a drift in the link, though at a later date, before the fall, there are a variety of intrigue others their success once molt position of this figure, saying only "group with communism (PKI)" very successful set direction step on this figure by bringing forth what is known as the "NASAKOM" stands for the Nationalists, Religion and the Communism, during the Old Order serves as a way of integrating different factions in the Indonesian political direction. There is also the beneficiary in this merger is the Indonesian Communist Party (PKI). By doing this merger, PKI can enter the Indonesian government organizations, and with the entry into the organization's PKI makes it easy for expand its wings and begin to in still communism in the nation. Due to the restricted party PKI and also NASAKOM forbidden (1972, briefing material of Marhaen; and extracts from the book Authorship of Sukarno, in 1964, Di bawah Bendera Revolusi (under the flag of the Revolution)).

This understanding was made by Sukarno, with the aim to generalize across the bow of the political conflicting. There used PKI, Masjumi, PNI wing respectively. To be fair and not political clashes, Sukarno made a political Nasakom, consisting of:

$$
\begin{array}{ll}
\text { nasionalis (nationalist) } & =\text { PNI } \\
\text { agama (religion) } & =\text { Masyumi } \\
\text { komunis (communist) } & =\text { PKI }
\end{array}
$$

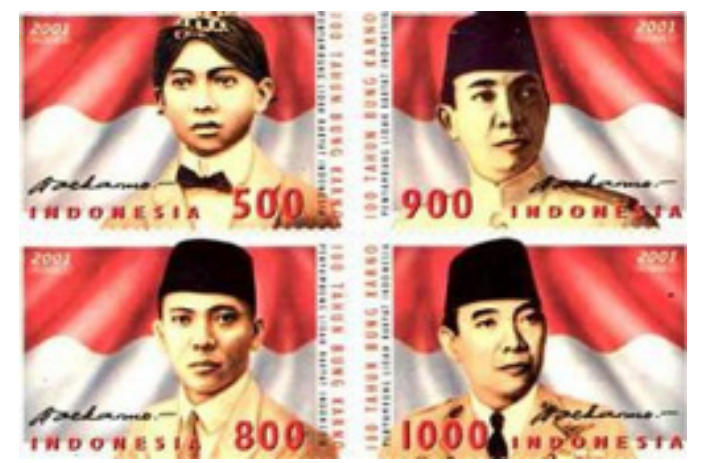

Figure 11. Soekarno, "Dibawah Bendera Revolusi”

This three understanding of Nasakom actually compete in war to win the hearts of the people's and became the largest political party in Indonesia. In fact, the PKI is more desirable because of programs that arouse people's hearts, such as free education, the welfare of workers, the emancipation of women, social justice and more over to seize West Irian (Papua). 
Nasakom be understood that banned because of its involvement in the G30S, which is still vague. Mainly because of the word "kom" behind Nasakom. Nasakom own paraphrase of Pancasila which each contain meanings precept sof religion, the communists and nationalists.

principle 1 : agama (religion)

principle 2 : komunis (communist)

principle 3 : nasionalis (nationalist)

principle 4 : demokrasi (democracy)

principle 5 : komunis (communist)

The name of Sukarno has a huge magnet, speeches so jarring and foster the spirit of nationalism and now the Soekarnoist still believe that the charismatic Bung Karno is a great leader who will never be replaced, and that is true.

Bung Karno as Nationalist Icon no doubt, from west to east of the country as embracing yet another side of Bung Karno as a teacher of the nation who also had Islamists sides, certainly not many people who know of them in his tenure marred by clashes of Islamist political circles and polemics sharpened base around the country with the most prominent figure among Muslims at the time, Mr. Mohammad Natsir. Necessary to underline that the love among Muslims to Bung Karno expressed a critical attitude and efforts correction of attitude and political steps of Bung Karno not with an attitude always sweet moreover treating. An attitude which is considered by some Soekarnois as attitude of counter-revolutionary, but throughout history of Islam political power, presented by Masjumi was always be a balancing force (the opposition) are always "loyal", the betrayal that ultimately comes from the Indonesian Communist Party (PKI) strategic coalition government of Sukarno joined in Nasakom are always trying consecrate itself as a force of the progressive revolutionary (idem).

The name of Bung Karno known as Putra Sang Fajar(Note 15)(Son of the Dawn) can not be separated from the figures of the Islamic Movement who were Istiqomah (bigfight) for the ideals of Independence of Indonesia, where the young Sukarno had lodgings at the house of Haji Oemar Said figures of Tjokroaminoto, leading figures of Sjarekat Islam, in addition to studying philosophy and Islamic thought the youth Soekarno also learned about the movement to the right people. Bung Karno really enjoy lectures and speeches of Tjokroaminoto which were so energetic struggle even under the supervision and suppression of the Dutch. Style speech of this teacher helped shape the leadership style of Bung Karno with typical speeches that loud and fiery, Islamism of Tjokroaminoto dubbed by the Dutch as the "king of Java without a crown" to some extent absorbed by young Sukarno. Although Bung Karno was finally chose his own path to move to Bandung and later founded the Partai Nasionalis Indonesia (Indonesian Nationalist Party, idem).

When in exile by the Dutch, Bung Karno always corresponded with Kyai Haji Mas Mansur, movement leaders and influential cleric from Surabaya close to the NU, later KH Mas Mansur believed to be the Grand Chief of Board of Persyarikatan Muhammadiyah and during the occupation of Japan established the Pusat Tenaga Rakyat (Center for Energy People/PUTERA (SON) and engage in joint struggle Bung Karno in the Four Ones.

Together with Mas Mansyur, BungKarno often exchange ideas about the dynamics of Islam and measures to facilitate the understanding of Islam, he expressed his disagreement with the attitude of imitation even explicitly criticize about the "hijab" or barrier between the congregation of men and women pilgrims, and many anxieties Bung Karno on Islamic issues, all of which showed the spirit and hope of a President Soekarno to Syiar Islam (Islamicsymbols) not going nowhere.

In addition, by KH Mas Mansur, BungKarno also often sent letters to the Tuanku A. Hassan, the Islamic leader the Founder Persatuan Islam (Unity of Islam/Persis) in Bandung. In the book "Di Bawah Bendera Revolusi" in 1964 these papers were co-invest. Bung Karno did not hesitate to ask the "sending" of Islamic literatures when he was in exile (idem).

On the other hand Fatmawati, the wife of Bung Karno known to be very religious, in a note at the meeting revealed that the giant Ikada Stadium which is now known as Gelora BungKarno, Fatmawati echoed verses of the holy Qur'an. Fatmawati the religious background as sessed also brings a considerable influence on political careers and life of Bung Karno until the end (idem).

Talks about Soekarno as a figure meant that the NKRI was and does remaining on the basic of Islam that is animated but also dominating the other understand (Javanese, Hindu, Christianity, even Communism and local wisdom) within Indonesia. 


\subsection{On Papua}

\subsubsection{The Process towards the Constitution Draft}

Subsequently this is directly correlated with the Constitution of the State of West Papua Script of 1999. The study results was earned by Papua Independent Committee (KIP) as ever reported to the public through the media of Tifa Irian in February 2000 and the Japan Shimbun newspaper by a French journalist June 6, 2000.

Although it is an ironic because only a mere shadow for failing to translate into products and Extraordinary Council agenda (MUBES) Papua in 29 February 2000 and as a logical consequence, there also appears at the Second National Congress of Papua 26 May - 3 June 2000. Just a disgrace history abandoned because it proves the folly of Papua achieve real political will has been presented completely by the Government of Indonesia through the President KH Abdurahman Wahid. That opportunity is as wide open as happened in East Timor under the President B.J. Habbie previous year (1998).

Nevertheless, it is not our desire to express it further because it has been fulfilled in the Third Papua National Congress it is by having ratified this Constitution becomes the Constitution of Papua Nation.

The desire to be realized is pushing the correlation studies that scientifically about to be revealed philosophical background that both parties (Nationalism of Indonesia and Idealism of Papua) can be brought together in relationships of the various conflicts that would be taken for the settlement of differences that exist.

The composition of the 1999 Constitution of Papua is initially back-up with interrelated items towards the content. These are prologue, introduction, specific agenda, genesis, and exodus. The mentioned items containing the concept of base philosophy gives insight forth is constitution.

\subsubsection{Prologue}

\section{THE LEADER OF PAPUA}

Jl. Bestuurpost 5, Sentani, Port Numbay

\section{LETTER OF DUTY}

Reg: 01/Legis.I/3/1999.

From: The Leader of Papua.

To: Papua Independent Committee.

Subject: Draft for Items of Governance of the State of Papua.

In the name of Father, Son and Holy Spirit,

I, the Leader of Papua on behalf of the Nation People of Papua in the Land of Papua and anywhere reside, referring to State Items of the State of Papua hence as Leader feel important to assign to Papua Independent Committee to collect data, studying and compiling Draft in the form of Logic, Elementary Ideology, Common/Public Governance, and Constitution of Papua.

That way, may to be achieved in fully responsibility.

Port Numbay 28 February 1999.

THE LEADER OF PAPUA,

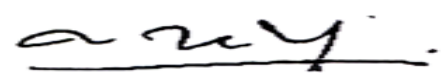

ONDOFOLO THEYS H. ELUAY

\subsubsection{Introduction}

\section{1). For the Last out Come}

The fundamental matter which will uttered here is that, have been happened various adjustment as according to political growth that happened since end of year 1999, and early year 2000 and the then growth till the Performing of Papua Extra Ordinary Deliberation (MUBES) 2000 dated 23 to 26 February 2000.

That by the successfully announcing of the Returning of the Name of Nation of Papua from the previous term that is Irian (Barat/Jaya) which is fully ugly connotation and which have hostility implication by the fourth President 
of the State of Republic of Indonesia, Kiyai Haji Abdurrahman Wahid (Gus Dur), hence, since the date of 1 January 2000 the news have had an effect on to give understanding pattern of the importance of resettlement and change in all life scale for example abstracting War Sections of Triple Command of People (TRIKORA) 1961 because going into effect for the vanish West Irian and or Irian Jaya but non for Papua.

By itself the Term of West Papua of that is stated at previous Sections will enough only mention as Papua. This consideration besides inline with the announcement of the President mentioned above, also utilize to accommodate to return to Political Manifesto production results of Papua National Committee 19 October 1961.

Others, there is also dissimilar specifics especially concerning substations of section and Transitional Governance and also the duty function of relevant institutions.

That way can make enunciated for all wearer. Thank.

Port Numbay, March 2000.

Compiler

\section{2). Introduction to the First Outcome}

The Struggle of the Nation People of Papua in Papua have arrived at more existing arrangement as according to organizers order as claimed in civilized association and modern political stratum.

Utilize to equip and greet all these, the Papua Independent Committee is very stubborn because had been entrusted by the Leader of Papua, pursuant to Letter of Duty, number 01/LEGIS.I/3/1999, dated 25 February 1999 to execute duty of mustering data, studying and compiling of draft as mustered in this writing.

Urging Prof. Dr. B.J. Habibie, the President of the State of Republic of Indonesia at the event of National Dialogue with the Society of Irian Jaya as response for the aspiration demand for the confession to the Independence of Papua declared date of 1 December 1961, hence as people believe in to make proper we climb to Praise Thanks to God Presence Which The most the Humane and Love for that Blessing. Those historic events which go on in State Palace, Jakarta dated 26 February 1999; make proper can be nicknamed as 'Sweet Rebellion'. This sheet have proved to the world that People of Papua own high customary politeness and which still be defended though the distress burden experienced as fruit of integration since year 1963 very much heartbreaking.

By Confidence and really Belief of the intervene God, hence the tradition politeness strength which still hold out that have squired up at stages of solving of free conflict of religion, tribe, gristle, race and free of convulsing.

This Performa may be created if we have known to realize the existence of each of us. Thereby, hence orchestrated strives, provocation, and even un-praised intention, by each party avoided surprised with have directive, that, 'definitive truth is God property Exclaim, Experienced All.

Attitude the existing condition and which will immediately rush about to go to a period forwards, hence from strong desire of various party to realize more orderly job mechanism existence according to existing demand in accommodating aspiration and acceleration of People Nation of Papua which is fought for. From existing understanding, hence, various parties also suggest, shall be formed through formula like intended by this Elementary Guidance.

That way, from consultancy result, uniting opinion and correct careful and also viewing various party for example Mr. Theys H. Eluay (Chief Institute of Custom Deliberation, the Leader of Papua), Mr. Herman Wayoi (History Perpetrator of the Nation of Papua), Mr. Herman Saud and Mr. Herman Awom (Evagelish Christian Church), Mr. Tom Beanal (Amungme Customary Figure), Mr. Yohanis Bonay, S.H. (Human Right Activist of ELSHAM) and also Mr. Octovianus Mote and Dr. Benny Giay (Irian Jaya Reconciliation Forum/FORERI), also various dissimilar name, hence, we are from Papua Independent Committee try to raise Draft of this Elementary Guidance.

As base for laboring of various concept forwards, Papua Independent Committee feel important to beforehand offer formula for idealism consisted in. Draft of this Elementary Guidance, in consequence comprise items in the form of Three Fold Logic Papua-Melanesia, Elementary Ideology, and the Public Governance, and also of State Constitution of Papua.

Though not yet completely correct, we have referring to documents in the form of United Nations Charter 26 June 1945, General Declaration of Human Right 1948, First Paragraph of Preamble Constitution of the Republic of Indonesia 1945, Resolution of The United Nation's General Assembly 20 December 1960 number 14 and 15, Papua National Committee's Manifesto 19 October 1961, Constitution of the United States, Constitution of Switzerland Confederacy, liberal and conservative view of Great Britain, and also the June World Labor Convention 1989 number 162, etcetera. 
From that existing contemplation, and constituted the existing local domestic cultural norm and also experience of 36 year integration with Indonesia, we arrive at conclusion that, however it's varying, life qualifier in existing tradition manner, Papua Nation is marked as owning dominant liberal and democracy indication. Finding of that's daring our tendency from Papua Independent Committee to specify liberalism and democracy as political vehicle of the People Nation of Papua. Will various problems faced by Nation People of Papua, is of course expected through political vehicle with this knowledge able to reply or at least drawing near at step of understanding of the problem and of course later also step the solving of it. Items compiled else than that, are also dribbled for have nuance of future in attitude the growth of global world in coming era. At least there is understanding of condition will two shares of Papua that is the State of Papua Nugini and Papua which later and start nowadays have seen to own tendency of unification become one state of Great Papua (Great Papua) start year 2003.

The early work may say, have been lapped over on the date of 7 March 1999 at the same time with Demand of Resurrecting of the name of Port of Numbay replacing Jayapura as the name of Capital City of Papua but because still be obtained dissimilar experiences especially of the Forwarding of Contemplative Result by the Team 100 to the Government of Indonesia, date of 24 July and also of miscellaneous concerning Contextual of Constitution hence this Draft can be finished jut now (ed. $28^{\text {th }}$ August 1999).

Still a lot of course which require to be completed at this Draft, but that's existence. Because representing shared problem which absolutely to be faced, we are very open to accept corrections and criticizes for the shake of the providing of pilot age for the Base Guidance desired with all.

Finally, presumably this Draft, can reach its exploiting and also for belief which is passed to Papua Independent Committee, we render thanks.

Port Numbay, Jayapura, 28 Agustus 1999.

Papua Independent Committee.

\subsubsection{Specific agenda}

\section{1). Check and Balance}

A Constitution or Basic Law proper to own the possibility of to be entered by the coronet instructing New Vision, Reform of System towards Civil Society. In the form of and early congeniality, constitution is static. Its base is to arrange organizational formation of the state about resident ships. But in modern congeniality at the develop countries go forward not merely conversing about static elements but also the dynamic elements.

At least there is fundamental starting point which must and can mirror in Modern Constitution that is democratic concept, state concept pursuant to law and prosperity concept besides certainly added with sovereignty or liberalism concept. Such obstetrical is not vaguely so that interpreted messing about as but as bare and shall realized by the existence completely. Each intentional component is proper to be mentioned clearly how the relation among one with dissimilar.

In meaning that presented by a Constitution shall represent integrity of check and balance.

Some tendency of proper public taken heed in compiling a constitution is:

- How is the process take place so that make proper for amendment?

- How is the domiciling of Congress in General Election mechanism?

- How is the domiciling of Executive?

- How level of domiciling and power of the President and Lead Governance (Prime Minister)?

- How must its time to defensive for a President and Lead Governance (Prime Minister) in period of power, ought to in how many year and period of General Election and also the pertinent may how many times entitled to be re-selected?

- How responsibility of a President and Prime Minister if experiencing different process between Election and selected direct by people, and also in the case of its responsibility execute Outline of State Bow (GBHN)?

- How is process and who is entitled to lift and agree for somebody lifted to become Minister?

- How is the process of authentication of Code/Law, who is entitled to raise the BILL, who prepare the BILL items, how long an authentication process, how to veto, how balloting in Congress to express veto?

- How the Congress, Lead of Governance/Prime Minister and the President lifted or directly selected by people in General Election, et cetera? 
In meaning, may not be given the possibility of prodigal interpretation and without considering. Sovereignty is onhand of the People, hence the arrangement even also be clear as there is no possibility for ambivalent.

If needed transfer or gift a mandatory hence shall be arranged later in AXLE JOURNAL followed with Code. Something component of legal force if told, will regulate hence shall be clear of its frame. This matter is to avoid fiction which far among a legal product with others. A Code, if will be replaced with newly Code, hence shouldn't to have too long distance in its differences. Others, that there is boldness or clarification, may not to be made source or reason of a legislating so that can cause to trespass Constitution.

\section{2). Amendment}

Though is confessed, a Constitution besides representing legal order is also an Ideology radiation. A Constitution in consequence does not have to hold sacral, hence thereby earn to be amendment so that obtaining more comprehensive form. It's had to be tested and continuously studied so that able to transmit democracy, justice, prosperity and sovereignty or liberalism.

In the life qualifier of state bearing, it is more beneficial to conduct amendment rather than changing Constitution. In executing amendment, Preamble is not at all bothered because containing historical values besides also avoid existence of debate of coverage which at all do not profit. In this case, only one Section in this Constitution that is Section 54, which is used as base. The arising out of discussions and debates is on facet of its juridical, in meaning only of its torso, just doing not bothering its Preamble.

In this case only translate its order of law, whereas the Preamble is not a Code but more common and global of its coverage. Amendment in that congeniality thereby will comprise adjustment and items completion.

\subsubsection{Genesis}

"God, The Lord Yahweh has created the universe and it's inert" as written in the Bible (Note 16), reflecting the fact of godliness as confessed by every human being".

Through personification and implementation of godliness, certain formulations and various terminologies of nicknames based on the cultural background and experiences in the life of humanity are created.

\section{1). Terra Australia}

The earth of Terra Australia is situated upon The Sahul Shelf and separated by into Australia and Papua or New Guinea with Tasmania and Aru since the latest glacial epoch. Studying the formation process of the sub-continent of Papua, it had undergone seven epochs. (Note 17)

1). Jurassic Period (170-140 million years ago);

2). Cretaceous Period (140-63 million years ago);

3). Eocene Epoch (53-37 million years ago);

4). Oligocene Epoch (37-24 million years ago);

5). Middle Miocene Epoch (15 million years ago);

6). Pliocene Epoch (5-2 million years ago);

7). Pleistocene Epoch (20 thousand years ago);

\section{2). Nova Guinee}

Period of latest notching, which is also referred as Pleistocene Epoch recognized now because following its inhabitants as Nova Guinee (New Guinea/Nieuw Guinea) or Papua.

The land features a length of $2.400 \mathrm{~km}$, a width of $740 \mathrm{~km}$ or an area of 792.540 square $\mathrm{km}$. Concerning West Papua itself, it stretches from 129 degree Longitude East to 141 degree Longitude East and 2 degree Parallel North to 10 degree Parallel South with an area of $421.981 \mathrm{~km}$.(Note 18)

The geographic structure of the latest formation reveals rich natural resources. The problem is how to make use of them for the prosperity of mankind, mainly benefiting its natives known as the Papua-Volken (Papuan tribes).

\section{3). Geographical Position of the State of West Papua}

Territory of the State of West Papua intended in this study is region of West Papua in composition of 1 December 1961 which in the year 1963 becoming West Irian then in year 1972 becoming Irian Jaya. As already mentioned above, geographically the such territory unfolding at 129 degree Longitude East abutting The State of Indonesia (Moluccas) to 141 degree abutting The State of Papua New Guinea, and 10 degree Parallel South abutting The 
State of Australian and 2 degree Parallel North abutting The State of The Philippines and The State of Palau (Micronesia) in the Pacific Ocean with broadness of 421.981 square kilo meters.

\section{4). Bowels of the Earth}

The existing perfection which is as now known, own resource of nature which abundance omit still how its management for prosperity of mankind especially tribes representing indigenous resident of this island or the socalled and mention its' self (Papua Political Manifesto 19 October 1961) becoming Papua-Volken (tribes of Papua)

The intestines of the earth consisting at least 26 different mining minerals or natural resources, among others nickel, cobalt, diamond, copper, manganese, silver, uranium, black tin, white tin, zinc, marble, opal, bismuth, chrome, coal, mica, arsenic, gold, aluminium, platinum, lime, asbestos, tungsten, oil and gas.

That attention also admits of again passed to dissimilar natural production like various useful wood type, cane, resin, palm oil and copra, coffee, cocoa, and crops planted and rice, inclusive livestock animals, flowers, flora, and the fruits. Also water produces like fish, prawn, crocodile husk, cockle, sea wets, and etcetera. Of course still have to be reckoned the air properties potency in sky curve of Papua for satellite and effort other sky space and also the source energy strength which is there are above or awakened from within its.

As the legal heir, The Papuan People in the State of Papua New Guinea and Federalist State of West Papua have to make use of these assets in an optimal way in the future. This may result in benefits for the wealth and the prosperity of all components of the nation in various sectors of life and also for the common interest of mankind on earth.(Note 19)

As creatures of God and a civilized nation, mutual respect and acknowledgment should prevail. This may be realized by a manner of life, which emphasizes on a harmonious neighbourhood as a family providing mutual benefits among human beings due to the grand arrangement of the Almighty God Yahweh, The Creator of the World Universe.

Realizing the blessings of God, which greatly overflows the Papuan earth owned by ethnic Papuans of Melanesian origin in Papua Nugini and West Papua; it is very much needed to formulate regulations for the common use or exploitation of existing resources.

\subsubsection{Exodus}

That Papua Volken (Papuan Tribes) is estimated to enter the Island of Papua 4000 years pre-Christian conterminous with Abraham went out from Ur Quasdim Mesopotamia (Iraqi) to the land of Canaan. It is very strong anticipated that countries in South-East Asia have represented land of sojourn or if not the so much regions of dwelling of Melanesian Ethnical with giant generation of as does Soloensis Erectus (ancient human being) whom was found its rawhide in Cangkaring-Solo, Central Java.

It is very much anticipated the ossify area of first sojourn was the Peninsula of Onin (Fakfak) now some epic before ice age melt. In the language of Iha, this event named "wanang-wanang" (water to become mucus).

From Onin, the human being of Melanesia gone the round of easterly and the west far before the earth surface erected became mount boost creating barricade insulation now. Hence it was very possible that the people of Asmat, Marind, Sepik, Sentani and Tanah Merah sharing the same origin of owning skilled and the same cultural root.

Colliding of the Pacific crust with Sunda crust have squeezed the Terra Australian continent or Sahul crust so that erected to the sky from the basin, mountains as giant abscess which hitherto still be witnessed.

The mass of water pouring from north horizon have disjointed Terra Australian become two that is Australian continent and sub-continent Papua and as well as with the islands of Tasmania and Aru.

Human being of Melanesia which stepped into Papua primeval was Melano-Negroid, Melano-Papua and later once was Melano-Wedoid. First group are resident of mountain and highlands, second are plain resident, area of bog and river boundary, whereas the third are resident of coastal area go out to sea and islands. If the third group pursuant to linguistic referred as Austronesian hence the first and the second group are Non-Austronesian or Papuan languages.

From that understanding hence the Papua Volken structured in 2 patterns of sub-ras that is Austronesian and Papuan own more or less 1.000 language (700's in PNG and 250's in Papua) and gone the round in more or less 11 Cultural Regions (6 in PNG and 5 added by 2 subs in Papua). Cultural Regional in West 


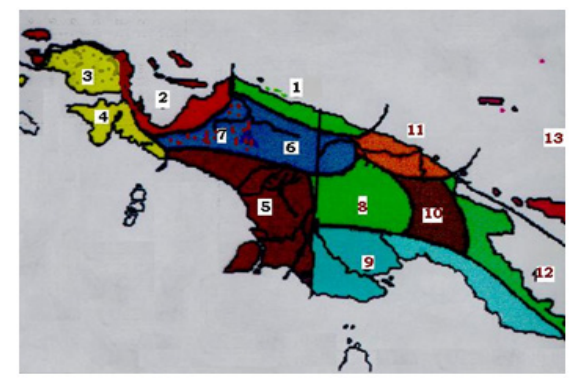

Figure 12.The 12 Customary-Culture Areas

Papua which later made of administrative base decision is:

1). Culture Area of Tabi (Mambramo-Tami)

2). Culture Area of Sarera (Geelvink Bay)

3). Sub-Culture Area of Domberai (Sorong-Manokwari)

4). Culture Area of Bomberai (Fakfak-Kaimana)

5). Culture Area of Ha-Anim (Merauke-Mimika)

6). Culture Area of Lani Paqo (Baliem)

7). Sub-Culture Area of Me Paqo (Paniai)

5.2.2 Law and Attribute of Papua

5.2.2.1 The 1999 Constitution of Papua

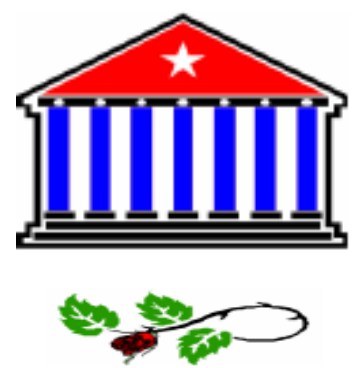

Figure 13.

5.2.2.1.1 Triple Fold Logic as Elementary Philosophy

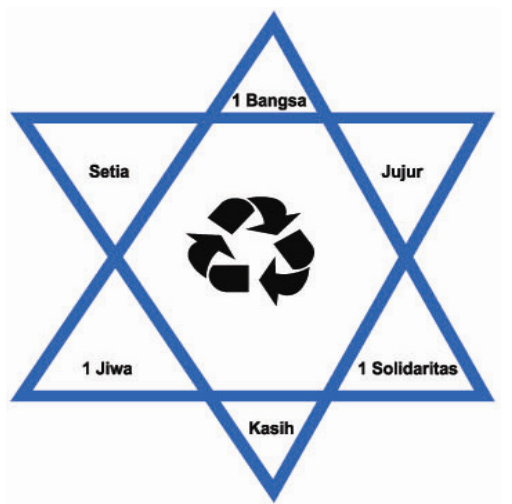

Figure 14. The Correlation of Triple Fold Logic

As a nation, which possesses features of customary modesty and nobility, we are also very aware of The Love of the Almighty God embodied by Jesus Christ as the Saviour of Mankind proclaimed by all prophets and rasuls strengthened with inertly august value and earth of Papua-Melanesia, hence exist implication of the Nation of Papua in qualifier of life of nation and state obliged to actively have integrity as part of world society. 
The reflection of the spirit is mirror in The Triple Principle of Papuan Luster: mercy, allegiance and honesty, (Caritatis - Fidelitas - Justitatis) in rhythm with The Triple Spirit of Melanesian Brotherhood: one man-one soulone solidarity (Unus Populus-Una Anima-Solus Solidarita) (Note 20) placed at 6 star angles. Its singleness becomes 7 correlation identity items from strength axis that is the Power God the Most Creator of the Earth and Sky epistemologically has correlation cybernetics and re-cyclical in ontology (elementary), epistemology (torso) and axiological (fruit of result) ravelled the followings:

1). Triple Spirit of Melanesian Brotherhood

The three items of The Triple Spirit of Melanesian Brotherhood are:

\section{One People (Unus Populus)}

The strong demand of realizing the reunification of West Papua and Papua New Guinea is to become One-Nation represents one of God's miracles. By possessing this generosity, The Papuan Nation is obliged to respond by dedicating its soul and body, thus creating the Island of Papua as a blessing to the world. The realization of unilateral corporation in a bilateral, trilateral or broader way is a demand to be fulfilled.

\section{II.One Soul (Una Anima)}

From the isolation and heathen power, the Papuan Nation was formed into One-Soul. The nature of One-Soul will be protected, as long as indignity, hypocrisy, selfish attitude, and apathetic and ignorant behavior do not pollute life. As imbalances emerge towards the nature of One-Soul, it may create disasters in the life of nation and society.

\section{One Solidarity (Solus Solidarita)}

Mutual help and responsibility encourages the establishment of a constructive attitude and ability of communication to build One-Solidarity. The One-Solidarity link arranges ways of mutual respect, mutual help and appreciation without hoping for a return. The dominant solidarity for the fellow members of the religious community is to worship Jesus Christ, Our Lord as the World Saviour, with the obligation of mankind to confess the existence of The Lord.

\section{2). The Triple Principle of Papuan Luster}

The three items of The Triple Principle of Papuan Luster are:

\section{Mercy (Caritatis)}

The emergence of the West Papuan Nation had only come true by the willingness of The Mercy or Love of Jesus Christ. In the name of The Triple Spirit of Melanesian Brotherhood Lord, Ottow and Geissler, two disciples from Germany, had crossed the sea and stepped feet on the island of Mansinam at Dorei Bay, Manokwari. This is The Lottery Land of God (Psalm 125:3), as stated for its baptism. In Namen des Herren Jesus setzen wir unseren Fuss auf dieses Land Papua (In The Name of Lord Jesus, we stepped our feet on this Papua land).

Love the Lord your God with all your heart, with all your soul, etc., and, Love your neighbour as you love yourself (Math. 2: 37-40). Love will defeat everything, so the enemies may be weakened to become friends. Giving love to other people is the manifestation of God's Love within the heart of mankind.

Whatever the experience is, it has been strengthening oneself through the medium of Love, where diverse Papuan Tribes are organizing themselves to become one nation, The Nation of Papua.

The Gospel of Christ worked horrifying: "After chucking The Head of this Bird Like Island, then the whole body on to the tail shined by The Love of Jesus Christ, from Sorong to Samarai".

\section{Allegiance (Fidelitas)}

The fruit of Mercy is Allegiance. This is being manifested as Allegiance to the Nation and State, which may be regarded as the Grand Commandment of the Lord reflecting His wisdom and knowledge. Allegiance is awaiting the Lord's Promises, giving hope to the Papuan Nation to realize their Independence and Sovereignty, which will be a miracle, $a$ gift from God. Allegiance in getting along with one's own promise to be a solid character as part of the nation, obeying and listening to the truth of the Lord and The Heart's Lustre of sincerity.

\section{Honesty (Justitatis)}

Another fruit of Mercy is Honesty. A modest and honest character creates peace because this may lead to mutual aversion of lying, overacting, exceeding undesirable limits, and, therefore, creating a balance.

Regarding this principle, I.S. Kijne, the prophet of Papua, in his vision once acclaimed. "Gene die op diet land waar en eerlijk daden deed en ook gehoorzaam zou blijven, mocht nog van de eene naar de andere wonderlijk 
kunnen beoordelen (Those who work in honesty and allegiance and also would remain obediently in this land, may experience miracle after miracle)"

The Triple Principle of Papuan Lustre of mercy, allegiance and honesty is able to create mutual completion, relating to psychological, spiritual, physical and environmental aspects.

The principle of Threefold Logic of Papua-Melanesian may be described in nature of complementary (Note 21) visible in 6 angles and 1 center.

In reality, above-mentioned aspects occur in life by occupying an appropriate circulation, which is well understood by each supporting group. The distributing in such a circulation pertain an axis although the level of rotation is not always equal because this very depends on forces from outside or inside. Comparing with the synergetic equilibrium of other cultures, this is seemingly very different.

The Western culture is, at its most perfect stage or cybernetic, conical structured. This develops from the very simple or uncivilized stage to more developed conditions, and subsequently leads to an established or civilized condition.(Note 22)As if for the Dravidan cultural pattern, which also includes Indonesia, the stabilized condition points to the establishment of the pyramid-civilization. This will continue to status quo before breaking-up into incarnation or say mandeg ing pandito and other appearances.(Note 23)

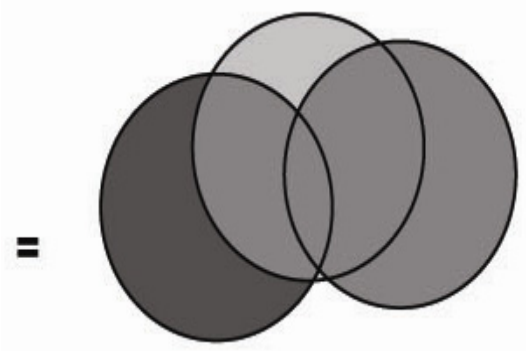

Figure 15. The Mosaic of Papua-Melanesia Triple Fold Logic

At this point, the synergetic equilibrium is formed as cyclic equilibrium but at each rotation a change of the cybernetic level of non-permanent nature may occur. This may only happen for the further phase to reach the rotating again in the cycles. On the above figure, the 're-cycle' nodes are symbolized. It may be stated that the cycle by itself is a cybernetic one or also called cyclical-cybernetics. However, the relation is not strict, rather indicating a hidden-structure however all components are reciprocal or equitable-complementary.(Note 24)

\subsubsection{The Charter of Papua.}

\section{THE CHARTER OF PAPUA}

We are by full glory and warship, admitting that, The Nation and Country of Papua, is under the authority and truth magnificence of God the Lord-Yahweh, Jesus Christ-The Peasant King and The Holly Spirit.

\section{AS COSMOPOLITANS WE, THE PEOPLE OF THE PAPUAN NATION}

\section{DECLARE:}

That based on the experience we have been undergoing, that colonialism of any kind and name being exercised by any nation is not suitable at all with humanity and justice, and contradict with principles of freedom and human rights, therefore, colonialism must be continuously combated and disappearing from the world's surface, so, for this reason,

Involved in bearing real responsibility for the sake of freedom and human rights, based on values and truth of humanity as an individual, by respecting aspects of gender and equal relationships between nation groups of small and weak between big and strong, besides preventing tendency predominate of big group or tyranny of small group, and also the experienced environment existence which remain to be peaceful and everlasting as source of humanity life, and,

Involved in establishing atmospheres which is allows developing possibilities for justice and respect as an obligation to enforce law and the truth on earth, and, Involved in promoting the improvement and restoration of life that is by approaching an appropriate standard ensured by freedom and full responsibility. 


\section{HENCE UTILIZE ITS MATERIALIZATION:}

Endeavours are required in full responsibility to The Papua-Melanesian Triple Fold Logic, that is The Papuan Principle of Triple Lustre of mercy, allegiance and honesty with full respect to The Triple Spirit of Melanesian Brotherhood principles of one people, one soul and one solidarity, that is,

Enabling the establishment of tolerance and peaceful coexistence among fellow mankind and among nations, and Involved in strengthening peaceful bonds, as an effort to create a safe and peaceful world, and is creating a serious understanding that the mobilization of forces does not present a useful solution, and creating conditions, which serve the fulfilment and prosperity of life for mankind.

IN THE FRAME OF THE MENTIONED PURPOSES, OBLIGED TO ACQUIESCE THE OVER VALUES POSSESS BY THE NATION OF PAPUA IN WEST PAPUA:

Immediately after gaining Independence and Sovereignty of the Papua Nation and Sate as on process declared 1 December 1961, we are determined to build ourselves as a Nation and State by establishing The State of West Papua Constitution as follows:

\subsubsection{The 1999 Constitution of Papua}

The State Constitution of West Papua consisted of 15 Chapter by 54 Sections and 2 Orders: 1). Interim Regulation with 7 Sections and 2).Special Order on State Attributions with 3 Sections.

\subsubsection{Review on the State Attributes}

The State Attributes of West Papua intended here are the National Flag, the National Anthem and the National Device, re-commented as follows:

\subsubsection{National Flag the "Morning Star"}

\section{1) General}

The Morning Star, is the National Flag of The Nation and The State of West Papua, flown in the whole Nederlands Nieuw Guinea since 1 December 1961 to 1 Oktober 1962 before this region administrated by The UNO (UNTEA).

The Flag which is generally used by the West Papuan population inclusive of the OPM (Papua Independence Organization) and all dissimilar supporters as a means of resistance and struggle for human right utilize to self determine. Almost every year on the same day that is every 1 December considered to be National Day of the Nation of Papua in West Papua, whereas at others considered to be an insubordination against domestic law of Indonesia.

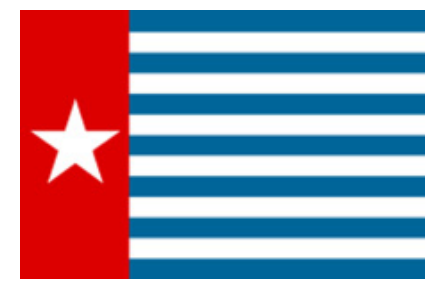

Figure 16. The Flag of West Papua

The Flag dimension is elaborated as consisted of a red plain unfold left long vertical beside showily at its center a white star five elbow while at right side there are 6 white lines alternating 7 blue lines symbolized 6 governance regions in 7 cultural or custom regions. In the Ordinance on the Flag of Morning Star it is not mentioned any size measure number, only the long and high comparison with the following ratio:

The Ratio of the Flag referring to that is A:B:C:D or 2:3:7:8, which is A: flag height; B: flag length; C: width of the red stripe; D: size of the star. All horizontal stripes are equal (so $1 / 3$ th of the flag height); The red stripe is $3 / 11$ th of the flag length; of the width of the red stripe; The star approx. $2 / 3^{\text {rd }}-7 / 8$ th of the width of the red stripe. (Note 25)

\section{2) Brief History}

The story was started, after a national election took place in January 1961 a Council of Papua or New Guinea Council (NGR) consisted of 28 members being cursed officially by The Governor Dr. P.J. Platteel in 1st April 1961 and formal constituted in $5^{\text {th }}$ April 1961 attended and witnessed by Governmental representatives and the State of Australian, United Kingdom, French, Dutch, New Sealand and dissimilar Nations from Pacific Forum with exception The United States of America. 


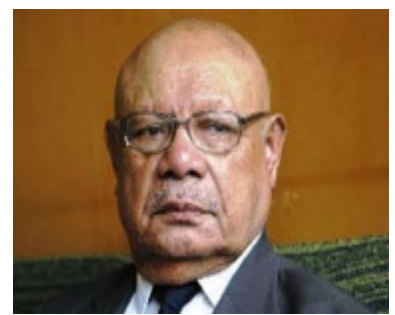

Figure 17. Mr. Nicolaas Jouwe, Designer of The "Morning Star" Flag

An emergency session insist on this Council at date of 19 October 1961 in response to news from The Hague Holland that US was allowing to launch per forcedly commercialize for its benefit Nederlands New Guinea to The United Nations to then delivered to Indonesian administration. The Council of Papua form Papua National Committee utilize to compile draft of Self-rule and Independence Manifesto, designed National Flag (Morning Star) and specify the nation hymn "Hai Tanah-Koe Papoea" The Council of Papua act fully, hence in 30 October 1961 the first Morning Star flag have been introduced to the Governor Platteel which is at 31 October 1961 announcement that "Have never been happened previously in world a Council own similar intention seriously".

Officially this flag was flown in one ceremony at 1 December 1961 with Mr. Willem Inury as The Chief of National Committee in his greeting, said "People of my fellow nation, you are now witnessing our union device and the desire of our union device and our desire to take place among world nations. As long as we do not really firmed up, we will not independence. To coalesce to mean to strive for the sake of our country, it is now, until the day which we will be self-supporting and that furthermore date from."

The chosen device of Flag is from the version of Nicolaas Jouwe (rather than 2 dissimilar versions according to Nicolaas Tanggahma and Markus Kasiepo). The version Morning Star Flag according to its designer who is Mr. Nicolaas Jouwe, is real inspiration by two device of Koreri Messianic Movement allied that are Cross flag (Star) and flag of octopus fingers and also the tricolor dark/blue-white-red (inspired by the flag the Kingdom of the Netherlands: red-white-blue)(Note 26) which was carried by all combatant under command of Papua Woman Warrior, Angganeta Menufandu in fighting the amber nation (incomers) before, during and thereafter the World War Two. The Royal Dutch Government then adopted this device become National Flag of Papua on 20 November 1961, hereinafter recognized by the name of "Morning Star Flag" that is Flag of Dawn Star" flown opening commencing from $1^{\text {st }}$ December 1961.

\section{3) Meaning}

As have been mentioned above at Brief History that the Flag of Morning Star is a mix-up between devices of Cross that is the Star and radius of octopus, later poured as blue lines and turn white. In payload of the Papua National Committee 19 October 1961, dawn star or morning star (the "sampari") is symbolized the Island of Papua in red field of political turbulence and development of the world. Else, the white line is of the six Governmental Divisions in seven cultural regions in Papua West.

The color of red, white and blue/dark according to interpretation of universal symbolism as also on the Dutch Flag ' Three Colors' and of the Indonesia Flag ' Red and White Flag'. That is red for dare, white for holy, blue for classy, and so on. The mixed-up is representing of elements in the culture and cosmos of Papua-Melanesia and those of Christianity.

\section{4) Regulation on the Morning Star Flag.}

Besides loaded in this shadow Constitution, regulation about the Morning Star Flag is also loaded in Papua Political Manifesto 19 October 1961 and the Governments-Regulation 48 Year 1961 and Governments-Regulation 70 Year 1961, on ordinance of the country Flag.

\section{5) Resemblance looks of the Morning Star FlagMorning Star Flag}

The equality of this flag is with the US Federal of stars and stripes and flag of Cuba which is incidentally true followed the example of the US Federal star and stripes, and also of the flas of Great Briten/United Kingdom.

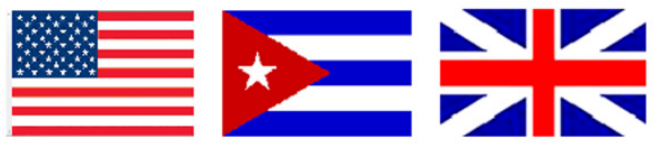

Figure 18. The Morning Star Flag bears a resemblance to Flag of the USA, Cuba and Great Britain 


\subsubsection{National Anthem of West Papua the "Hai Tanah-ku Papua"}

The title of song "Hai Tanah-ku Papua (originally: Hai Tanah-koe Papoea) is a volkslied (people song) writed in the year 1930s by Izaak Samuel Kijne, a Dutch missionary who also compile the spiritual song book "Njanjian Rohani". The lyric at this song is written in the Ianguage of Malay/Indonesia and Dutch, presented in 7 couplets. If carefully studied, idylls of this song containing worship of properties and natural beauty of Papua and terminated featly thank goodness to God of Creature of sky and earth.

This title have been electroplated by Dr. Thomas Wapai Wanggai changed to become "Hai Tanah-ku Melanesia", but seemingly not accepted off hand by the majority of Papuan because it is very known that this song have been specified as National Anthem of Papua with the like title in Political Manifesto of the Papua National Committee 19 October 1961 (Government-Regulation Number 69/1961)(Note 27) re-peeped out as preparation before The Papua National Congress Two year 2000 (this constitution). Story about the natural beauty of the Land of Papua terminated with Thanks to Cheap God, The Creator for the natural beauty which has been created for the Nation of Papua. That way, couplet by couplet may presented as follows:

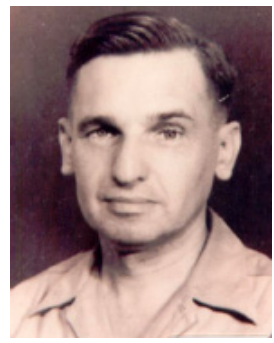

Figure 19. I.S. Kijne, Composer of NationalAnthem: "Hai Tanah-ku Papua"

\section{Hai Tanah-ku Papua}

\begin{tabular}{lll}
\hline 1 & 1 & 1 \\
Hai tanahku Papua & O mijn land van Papua & O my land of Papua \\
Kau tanah lahirku & Jij bent mijn geboortegrond & You're my birth ground \\
Kukasih akan dikau & Ik zal je een plezier doen & I'll give you a favor \\
Sehingga ajalku & Dus ik bedoel & So I mean \\
2 & 2 & 2 \\
Kukasih pasir putih & Ik geef je wit zand & I give you white sand \\
Di pantaimu senang & Op je strand, gelukkig & At your beach, happy \\
Di mana lautan biru & Waar is de blauwe oceaan & Where is the blue ocean \\
Berkilat dalam t'rang & Glans in t'rang & Gleam in t'rang \\
3 & 3 & 3 \\
Kukasih bunyi ombak & Ik laat de golven klinken & I sound the waves \\
Pemukul pantaimu & Je klopper Altijd aan het zingen & Your beater Always singing Happy my heart \\
Nyanyian yang selalu & Blij mijn hart & 4 \\
Senangkan hatiku & 4 & I love the mountains \\
4 & Ik hou van de bergen & Great and exalted \\
Kukasih gunung-gunung & Groot en verheven & And the clouds that float \\
Besar mulialah & En de wolken die zweven & Above their peaks \\
Dan awan yang melayang & Om hun toppen & 5 \\
Keliling puncaknya & 5 & I love the woods \\
& Ik hou van de bossen & That cover my country \\
5 & Het dekkleed van mijn land & I love to roam \\
Kukasih hutan-hutan & Ik mag zo graag zwerven & Under your shadow \\
Selimut tanahku & Onder je schaduw & 6 \\
Ku suka mengembara & 6 & I love the land \\
Di bawah naungmu & Ik hou van je grond & That your people \\
6 & Die met je vruchten & Pay my zeal \\
Kukasih engkau tanah & Mijn ijver betaalt & And my work \\
Yang dengan buahmu & En mijn werk & 7 \\
\hline & &
\end{tabular}




\begin{tabular}{|c|c|c|}
\hline Membayar kerajinan & 7 & Thank you Lord \\
\hline Dan pekerjaanku & Dank zij u Heer & You've given me the country. Let me be \\
\hline $7+1=0$ & Gij hebt mij het land gegeven & diligent. In order to meet your goal \\
\hline Syukur bagimu Tuhan & Laat mij ook ijverig zijn & \\
\hline Kau berikan tanahku & Om het laten beantwoorden aan & \\
\hline $\begin{array}{l}\text { B'ri aku rajin juga } \\
\text { Sampaikan maksud Mu }\end{array}$ & Uw doel & \\
\hline
\end{tabular}

\subsubsection{Coat of arms of West Papua 'The Mambruk'}

The Mambruk or crown pigeon is a species of bird referred to in Latin term by Gaura Regia Victoria Papuana that is an endemic species which is only found in the Land of New Guinea (PNG and West Papua). So far not yet there any consensus comes up with the picture of this bird which is looked like Garuda Panca Sila and Hawk of the United States with its payload.

The concept of initiated by Papua National Committee as rearranged by Papua Independent Committee drawn hereunder is at the chest shownTriplefold Logic of Papua Melanesia in the form of clasp of cybernetics relating flag of Morning Star attached by a frontage (red field and the white star) from the top and the backside (blue and white lines) downwards as described at above semicircle Caritatis-Fedelitas-Justitatis (Mercy-Allagience-Justice) and below this described Unus Populus-Una Anima-Solus Solidarita (One People-One Soul-One Solidarity).

Where as the bow and drum flanked at the feet are unclear but bold of that appliance both are applicable for two intentions which each other complimenteray that is fight for the peace or on the contrary also make peace to battle.(Note 28)

Why chosen the Bird of Mambruk, this is according to utterance of Mr. Nicolaas Jouwe who is the designer of that Attribute of the State of Papua "... [taken away froma Biak language mam 'bird' and bruk 'reminding', blazed abroad it is true represent totem in life of various tribe in the Land of Papua; that this beautiful bird striving without a lot of voice to differ from other birds; the voice of bird which is almost life above on land and flight low is very rare heard; masculine bird in every day only twice release its voice that is at the morning in when descend on land to start life one day and in dusk when fetch night before sleep. Because of its high philosophic value, by the Papua National Committee notching of Nieuw Guinea Raad in its conference of First Papua National Congress 19 October 1961, specified to become Attribute of the State of Papua which have principality: Unus Pupuli-Una Anima (One Nation-One Soul), which then by Papua Independent Committee in 1999 developed addedly the Solo Solidarita (One Solidarity) principally adding with Devoted, Amicable and Downright analogue with that of Papua Independent Committee of 1999 becoming Love/Mercy (Caritatis), Devoted (Fidelitas), Justice (Justitatis) as have been studied at Elementary Guidance (see Triple Fold Logic of Papua- Melanesia). (Note 29)

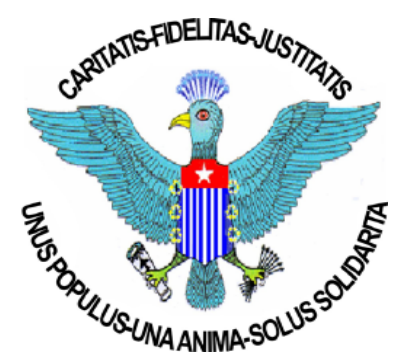

Figure 20. Coat of Arm "the Mambruk"

In this bearing with existence of RI Law number 21 Year 2001 about Special Autonomy for the Province of Papua/Otsus, almost always the elite Papuan especially the Papua Customary Council (DAP), Papua People Assembly (MRP) and some of Parliament members of the Province of Papua want those Attributes of the State of West Papua made to be Area Device of Papua Provinci according to such commendation of the OTSUS. But seemingly the God do not want that way because to the proffering of Perdasi/Perdasus on this aspiration hadslapped down by the President of RI as an Allah Slave to save National and Political Devices of West Papua inclusive that 
of Atjeh and Moluccas from insult to become Area Device launchedly of the Governmental Regulation Number 77 Year 2007, hence remain to be endless intended as Device of a State and Nation, non merely highness device of an area in The State of Republic of Indonesia. Of blessed on all struggles which are for the shake of truth spirit of the Nation of Papua warshiping God all the most Big.

\subsubsection{Correlation of both Constitutions}

With the Original Text of the 1945 Constitution, in the Amendment Manuscript as shown, there are a number of things that should be noted, namely:

1. In the Amendment Manuscript the word Opening (Pembukaan) is used, not the Preamble as in the Original Manuscript.

2. On the Opening of the Amendment Manuscript located inside is published as part of the Constitution while in the Original Manuscript; the Preamble is outside or separated from the Constitution.

3. The contents in the Opening of the Amendment Manuscript is longer than the Preamble on the Original Manuscript.

4. The contents of the Original Manuscript consist of 14 Chapters with 37 chapters, 1 Transitional Rules with 3 Articles and 1 Additional Rule with 2 paragraphs while the Amendment Manuscript contains 16 Chapters, 37 Article 1 Transitional Rules with 4 Articles and 1 Additional Rule with 2 Articles.

The Other matters are:

1. Here the State boundary from the coordinate point and place name is not mentioned, is it really not such intentionality? Need input for improvement in amendments.

2. Since 2009 for the first time direct elections by the people have been held in Indonesia; in the sense that the Fourth Precept is no longer merely obeyed.

About the full text can be seen in the Original Manuscript of the 1945 Constitution of the Republic of Indonesia by the National Legal Development Agency, Ministry of Law and Human Rights 1998, while the Amendment Manuscript can be seen in the 1998-2003 Development Reform Cabinet TAP MPR No. II/MPR/1998.

In comparison to the 1999 Constitution the author is based on the Original Manuscript of the 1945 Constitution before the amendment so that there appears to be a correlation. But there are also other advanced steps regarding the natural environment, human rights, the ownership of armed forces and others which are not raised in the original Manuscript of the new 1945 Constitution and then appear in the 1945 Constitution Amendment Manuscript.

\subsection{Referral Reflexive}

To get an understanding of both Constitutions and the related supporting materials (Garuda Pancasila, the Flag of Dwi Color, Anthem Indonesia Raya, vis-à-vis the Basic Guidelines Papua-Melanesia, Triple Fold Logic of Melanesian-Papua, The Charter of Papua Nation, the Flag of Morning Star, and Mambruk-Goura Victoria papuana regia), then the comparison step is indeed not very appropriate in used. This is because both have complementary side and the reference in this case the interests of the Nation of Papua for sake of the nobility names of the Nation of Indonesia. While on the other hand the greatness of Indonesian name for the glory of God's name for the nation of Papua and universal humanity.

Only people allowed (by God) to think in that direction and that may gain the ability to digest and crucial in the face of both these texts as "from one mark to wonder and to mark another wonder". So this study should only be approached descriptively normative correlation to uncover each in the following narrative:

\subsubsection{Materials}

To understand reference of this Reflexive is directly to the Constitution as the main materials. Thus of the Triple Fold Logic of Melanesian-Papua starting when include the Foreword of Papua Leader, Chief Theys Hiyio Eluay, Genesis contains the formation of the island of Papua in seven epic, Exodus contains among others Papua Volken as discussed by Researcher from the Van Vollenhoven Institute in Sub-Chapter 3. The materials referred to it can be used as background knowledge as Soekarno write Pancasila and the Constitution of 1945 with dogmas which among other things contained in Tan Malaka, 1925, Mohammad Hatta1928 and Sukarno himself 1933, namely Islam and Nationalism or also serial writings of Sukarnoin 1954 titled "Di Bawah Bendera Revolusi (Under the Revolution Flag)".

In this particular, there is connection among Islam and Nationalism in Pancasila and the Constitution of 1945, while Triple Fold Logic is rooted in customs and to Christianity of Melanesia-Papua as basis for departure. 
Correlation is the strength of adhesion of the understanding is no action to build a pyramid of Unitary Indonesian Nationalism tolerance that is displayed in the "Unity in Diversity" (Diversity in one) while others in Papua meant is gluing the mosaic that is From Unity maintained differences that occurs and takes One Solidarity to glue One Nation and One Soul raised with Mercy, Allegiance, and Honest.

\subsubsection{ItemContemplation}

In the content of Pancasila, each item stand separated and alone though indeed co-exist, while for the correlation of the items in Triple Fold Logic of Melanesian-Papua, each cybernetic cylindered uncontrolled manner (circulating or shaft continues spinning in recycling). The divinity or Godhead in the First Precept of Pancasila is denoted with a star in the middle of the chest of Shield Garuda Pancasila correlated with Triple Fold Logic the divinity or Godhead that is the power of cyber moving six horizons toward and moving by the star.

Belief in God Almighty is in Pancasila for the Triple Fold Logic seen as the Creator of Heaven and Earth the Yahweh therefore providing Loving and Long-Forbearance.

Mercy, Allegiance and Honest are divine commands that humans lived in One Nation, One Soul and The One Solidarity. The elements in the Pancasila radiated in the four precepts, namely Humanity Just and Civilized, Unity of Indonesia, Democracy Led by Wisdom in the Consultative/Representative, and, Social Justice for all Indonesian people to perform independently represented symbols of Banyan Tree, Head of Bull, Rice Grains and Cotton Boulders along Chain strands, correlated with grains of Triple Fold Logic not represented by emblem in the sense of a straight forward and does not require interpretation.

\subsubsection{ConstitutionCharges}

About the load on the Constitution of Indonesia 1945 comprises 16 Chapters plus 37 Articles and the Transitional Provisions 4 Articles, while the Constitution of Papua 1999 contains 18 Chapters with 54 Articles and Additional Rules with 7 Articles of the Transitional Provisions as well as the Special Rules with 3 Articles. Existing composition impressed balanced in the sense of not much to unravel as the Constitution generally allows can happen poly-interpretable so that it takes so much tightening through the Acts and Regulations as law enforcement tool.

Apparently the experience during the integration and knowledge of the Indonesian Constitution of 1945 (P4) inspires the Papua Constitution of 1999 so that it may avoid and even away of or at least reduce problematic polyinterpretable intended above. Impressed corrective action has been perceived conditions, although further idealism to build an edenic circumstances or an ancient of Melanesian-Papua as alleged by Researcher from the Van Vollenhoven Institute of Legal intended above.

One example is in Indonesian Constitution 1945 Chapter X, CITIZENS, Article 26 (1) The citizens are the indigenous people of Indonesia and the people of other nations who passed the law as a citizen; (2) The requirements regarding citizenship established by law. While the Papua Constitution 1999 this subject reads CHAPTER IX CITIZENSHIP, Article 32, Citizenship (1) The citizens are ethnic Melanesian-Papuans and the Ethnic of others duly authorized under the Act, (2) the State of West Papua recognize and respect the dual citizenship extent not inconsistent with the order of life adopted in the country; (3) The terms of citizenship of the State of West Papua stipulated by the Law. In a more straightforward meaning for ethnic and citizens of other nations who wanted to recognize the existence of Papuans. This correlation is returned to the plight of the ethnic Chinese in Indonesia's New Order era are barely respected the rights of the essence in this case concerns the name and surname of its ancestors.

Ten years after The Hague RTC (Round Table Conference) and before integration into the Republic of Indonesia although short but has formed einheid Papua Völken (Unity of Tribal Nation of Papua) that still implies impression and awareness of Papuan identity is an other in a correlated outside the United of Indonesia (an effort into Indonesia and necessarily requires various forms of reward or appreciation as fellow citizens inequality of dignity).

\subsubsection{Bounders and the Form of State}

The Border of the State is not the same according to both constitutions stated evenly. Is nil in the Indonesia Constitution 1945 while the Papua Constitution 1999 mentioned in Chapter I, Article 4:

(1) The territory of the West Papua stretches on 129 EL degrees bordered by the State of Indonesia(Maluku) to 141 degrees EL is bordered by the State of Papua New Guinea, and1degree of NL is bordered by the Philippines, the Republic of Palau and the Pacific Ocean to 10 degrees SL bordered by Australia. 
(2) The Territory of West Papua is divided into 7 Regional Territory with the distribution of residency and Gemeente (Municipality or Community).

(3) The Territory of West Papua happened because the development was then called Afterwards Agglomeration Territories or the Then Development Territory, regulated by Law.

(4) The State of West Papua is shaped Common wealth in form of Federation (Federalists State).

Forms of the State according to both constitutions is stated equally; according to the Constitution1999 (of Papua) mentioned in Article 5:

(1) The State of West Papuan comprises Federalist by a Mix-Cabinet of Parliamentary and Presidential;

(2) The Government of the State of West Papuan comprises 7 Traditional Territories of Papuan Folk according to the Manifest of The Papuan National Committee, ascribed as strips on the National Flag, The Morning Star, 1 December 1961 which are Hollandia or Tabi, Geelvinkbai or Sarera, Vogelkop or Domberai, Onin-Bomberai, South Coast or Ha-Anim, Eastern Highland or Lani Paqo and Western Highland or Me Paqo and also of Afterwards Agglomeration Territories.

(3) The Afterwards Agglomeration Territories are basing on the division of Second Level Governance of Province of Irian Jaya or also to Governance of Special Autonomy (OTSUS) Province of Papua and or other condition and consideration and also the other support.

(4) The determination of Traditional Territories and Afterwards Agglomeration Territories will be further arranged in the Legislation

\section{Meanwhile Form and Sovereignty in the Constitution (Indonesia) in 1945 declared Article 1:}

(1) State of Indonesia is a unitary state with a Republican form.

(2) Sovereignty is in the people and done entirely by the Assembly.

There area variety of other matters concerning Health, Environment, Citizens Rights and others, but in order to avoid a comparative understanding (comparing), the performance is not forwarded. Subsequently it is forwarded by tracing the correlation between the symbols and the attributes on each.

\subsubsection{About the National Flag}

About the National Flag, the Two Color Flag appears in a period of political and the physical struggle against Dutch colonialism ended after World War 2. Red and white colors imply a peaceable but for that, war could even happen. Colors are by animation or precisely copied on the flags in the Middle East that are Islam breath. Correlation with the Morning Star Flag, is, a delivery back or a reincarnation of the symbol of resistance against Amber or foreigners (non-Papua) by fighters of Koreri before, during and at the end of World War II with inspiration Morning Star in myth of Manarmakeri which is the forerunner of Koreri beweging (Koreri movement) as illustrated by Kama (1972). If echoes and dogma at the end of World War 2 is "going to create peace, true comradeship and liberty for the all Nations", so the Papuans are included in the Dutch East Indies Colonies Countries that were released in 1943 two years before the proclamation of Indonesia announced by Soekarno and Hatta. Thus Morning Star flag is the symbol of intimacy (mosaics') customs and to Christianity of MelanesiaPapua in terms of struggles (resistance or movement) of Koreri anti amber in question is at the same time anticolonial.

Correlated these, both flags are equally emblem of struggle, despite different shades. Events in Oranje Hotel Surabaya showed Dwi color occurs because the blue stripped of Tricolor on part of underneath, while the Morning Star occur because of the completeness distributed by tricolor complement local knowledge and ideology of Papua. Then releasing the Tricolor the Morning Star just joined Dwi color were not able to accommodate the image. Morning Star hostility thus no space and hindered other efforts to realize the dream of a prolonged in Papua of time continues to take its toll as both Dwi colors flag and the Morning Star. Chief Theys Hio Eluay ever take the initiative to raise the two flags together on December 1, 1999 events as the beginning of true comradeship Indonesia-Papua, but instead blame. This event because it is the reason for this man arrested and prosecuted along with 4 other figures is The First Jayapura 5 December 2000. There Autonomy was not a decent place to position of the Morning Star became a local or area symbol. Thank Thy God, as so the flag remain national symbol of West Papua Nation.

\subsubsection{About the National Emblem}

About the National Emblem of the two peoples is naturally appearance of a form of bird. A philosophical correlation looks at compliance birds of "mambruk" (crown pigeon) do not talk much but put forward the hard 
work, and the "garuda" (eagle) that also does not talk much, but claws and beaks capable counting in seconds. Strong and powerful in savage breast correlated with the toughness of a peaceful life in crown pigeon or dove ellegant crown in blue sheen. Indeed, so much correlation data but not yet realized both parties, especially the Indonesian defense that is in control and know better "what freedom is the right of all nations....." then it maybe able to defend the position of both nation.

\subsubsection{George Junus Aditjondro on Factual and Contextual}

This section is an adaptation and reviews of George Junus Aditjondro (1993), according to Clifford Geertz cultural duality theory on the facts among others the correlation shown above, by borrowing the experiences and statements of Otto Syamsuddin Ishak, senior researcher at Imparsial, Jakarta (2012, http://himasio-unsyiah.blogspot. com/2012/03/ otto-syam-sudin-ishak-nasionalisme-kita.html) in Aang Ananda Suherman,http://bahanamahasiswa com), that, herein lies the difference between Aceh (when categorized as Indonesia) and Papua in relation to the cultural duality theory, because Clifford Geertz once visited Aceh so logically, when he charted Indonesia Outer, Aceh included in here. When he describes how the Java possess religion, has been unimaginable at the end of the world there is Morocco(North Africa) and in the end of Sumatra there is Aceh, which is bearing Islam in different ways with Java.

Geertz'sviewis a lotof writing and articles and books among them (1) Interpretation of Cultures: Selected Essays 1973; (2) Works and Lives: The Anthropologist as Author1988; (3) Local Knowledge: Further Essays in Interpretive Anthropology 1983; (4) After the Fact: Two Countries, Four Decades, One Anthropologist 1995 and (5) Available Light; Anthropological Reflections on Philosophical Topics 2000.

The books are mostly based on field studies in Indonesia and Morocco. He focused on two main topics, namely economic and religious. On the economic element, comes with what is called involution concept (concept of involvement or hassle concepts). Syamsuddin Otto Isaac said, according to the concept, a tiny plot in Java is forced to absorb unlimited supply of labor and cultivates the land until the soil is exhausted.

In correlation above shows how the collision of environmental concept according to Article 33 of the UUD'45 and Article 51 of the Constitution 1999 whichled to the using of "Lingkungan Hidup" (Life Environment) in Indonesia versus respect for the "Lingkungan Alam" (Natural Environment) in Papua (Melanesia).

In economics, said Otto Syamsuddin Ishak again that, there is an interesting fact that the theory presented by Nobel prize winner Arthur Lewis, namely"the economy of unlimited supply of labor" which essentially outlines the possibility of a transition based economy from agriculture to industrialization.

It said, "The industrialization continues to happen because the change of labor from agricultural sector to industry will not affect the productivity of agricultural sector since the labors' marginal productivity of labor/MPL) drawn as: MPL $=0$ or not at all mean. This theory has destroyed views of economists such as Ranis and Fei(2010), Theory of Economic Growth; https://olga 260991. wordpress.com /2010/04/07/teori-pertumbuhan-ekonomi/)(Note 30).

What is interesting is the theory that Lewis could not be presented here as a new theory when confronted with cases set by Geertz of what be the so-called concept of "shared poverty" as part of the theory of the agriculture involvement.(Note 31)

While in Papua Melanesia as stated by J.G. Held (1951) as "kultuur improvisator (culture improvisator)" is the opposite of the horizon is very contradictory. An example that, to trade as catering for Papua not departing from the bear, carts, bicycles, motorcycles, cars, hawkers and home stores and trade, but the right is the result of the field to the home store or even to commerce and industry. Or roughly said "illiterate can be controlled from the tractor and needs of the times (using a mobile phone in a state bearing penis cocker "koteka")". Held's statement may be mentioned having seen a decade (1949/1950-1960/1961) the development of the community in the Netherlands New Guinea (including the Melanesian society in general).

Methodologically, there is difficulty to read Papua. Is when outlining Indonesia in to two cultural systems Geertz have imagined that Papua became part of Indonesia Outside? Or do as Researcher from Van Vollenhoven Instituut above, Papua positioned as marginal line cosmopolitan lies in Indonesia.

Papua was not added in culture duality map of Geertz. According to George Junus Aditjondro, fortunately Papuans them selves have a different definition of the citizens of Indonesia, namely Papua(haired) curly where Indonesia is (haired) straight. This is what can be used as a basis for reading Papua from the perspective of cultural duality. In this context, it is used for things relating to the history and expansion (or separatism) in Papua internally as revealed Otto Syamsuddin Ishak. Which in this case must be experts such as Geertz did not even imagine that the "culture of Papua was not part of Indonesian culture" in the sense of not included in the different but one or tolerance of "Unity in Diversity" as the basic characteristics of Papua is solidarity of "Together in Diversity". 
Papuans tend to be resistant to the writing of the history of historiography Indonesia-centrist Papua perspective. For them, all the political circumstances which reconstructed "it is not straight, but very, very curly", continuing Aditjondro. Uniquely, they are constantly fighting for what they call "historical rectification of Papua". This is a political pamphlet that is congruent with the book title Subandrio (2000) on the political history of Papua in relation to Indonesia, namely Straightening History of the Struggle of West Irian. Should not it be "consistent with the attitude of dualistic culture". The Papuans actually are struggling to crimp the history of Papua that has been straightened by the ruling elite in Indonesia? Although it is not easy to imagine as described by Demmy Antoh (2007: 177) that is on the implementation of the mandate of Article 46 of Law-Decree No. 21 of 2001 on Special Autonomy for Papua Province, concerning the Truth and Reconciliation Commission that is certainly inhibited Jakarta by all means.

The second thing is about the political division of Papua (2003). How can Indonesia held internal separatism in Papua? Is the Indonesian elite solely consider the geopolitical Indonesia and Papua geo-culture ignore? Aditjondro again mentioned, "geo-politics defined unilaterally by kaum serdadu (the defense perspective) of everlasting invasion (immortality occupation). While on the other hand is also to address the development of stagnant because of the wide range of services and governance if they are only in one province and it is possible in accordance with Article76 of the Law-Decree No. 21 of 2001 on Special Autonomy for Papua Province.

Indonesia-centrist historiography which, according to Indonesian experts, just mentioned Bambang Purwanto in Ibrahim Isa Alias Bramijn, (2007, http://www. kabarindonesia.com/beritaprint.php?id=20070121023717), Bambang Purwanto had failed. However, perhaps not entirely failed or unsuccessful. There fore, in relation to the history of Indonesia versus colonial party, perhaps the time of writing still holds the principle of decolonization, although his form is still dominated by stories of the movement in the area around the center of the colony, the Batavia. However, history in relation to the relationship between Jakarta and the regions may actually still colored by the spirit of colonization that is strong, with the exception of Papua in certain respects be seen as a process of integration that can only assumption was turned in to a feeling occupied by foreign parties when acts of vandalism, brutality, mistreatment, harassment against the identity of Papua continuously waged.

According to Aditjondro, in fact, when seen at a glance at the history of Papua, the writing is a continuation of colonial-centrist alone. Papua is in the Dutch-Indies historiography-centrist and continued into Papua is in the historiography Indonesia-centrist. The problem for the Indonesian side, there is a strong interest to maintain the image of political morality if it's history as told by Bambang Purwanto is a ratio that reflects the events, emotions, and black-and-white subjects from Indonesia or Papua.

In terms Indonesia-centrism, Papua acquired through the chaotic struggle between the invasion of troops and diplomatic action. As if, with both actions said, the colonial subdued before the rooster crows, as the story of establishing of Prambanan temple or the famous lake and mount Takuban Prahu in Javanese and Sundanese communities.

In fact not the case, because there are processes the political negotiations of bilateral political treaty between Indonesia and the Netherlands on August 15, 1962 in New York, and the subsequent negotiations. There are provisions in the Declaration of the United Nations and international laws which were ignored, the time will demand to return as a deliberate offense violation of truth. New York Agreement consists of 29chapters, which among other things regulates the transfer of government of the Netherlands to the United Nations and the Secretary-General formed UNTEA government until May 1, 1963. Then UNTEA handed Papua to Indonesia until the act of self-determination freely implemented.

Although only 1 (One) voice which was Eduard Hegemur of Election Pool of Fakfak, another voice requires independent and separated from the Indonesian nation and the Netherlands contrary to the choir orchestrated by Indonesia. Although only one voice, it is an eternal truth that should come out of the mouth of 1020 members of the DMP (since 1 vote resign) compiled by Indonesia for deliberation-consensus-mutual help respond to international law "one man-one vote" New York Agreement in 1962.

From the side of Papua-centrism, the Papuans have the desire to break away from the Netherlands, but it is not automatically submit itself to Indonesia. Because, Papua is not a Dutch East Indies, as is Indonesia's political conclusion. Papua nor is a colony of the kingdom of Tidore, which is then captured by the Dutch, then seized by Indonesia from the Dutch.

On the matter of self-determination, Indonesia got the political gap of the absence of a system setting and selfdetermination in the New York Agreement. UNTEA did not prepare for it during its rule in Papua. Indonesia then made a model of its own, namely the Act of Pepera, which corresponds to the political and ethical culture of Indonesia "gotong royong (mutual assistance)", as well as negotiate its own time (1969). The act became a series 
of actions of the determination of 63 chiefs, 89 deputy group, and 88 representatives of youth who mobilized at 3 to May 6, 1964. Apparently, the political practice of the determination made in areas of conflict such as East Timor and Aceh is a continuation of Papua political practice in the post-Treaty of New York in 1962.

Political policies and the behavior of Indonesian politics so curly that self-determination does not reflect the existence of freedom of choice on the one hand, which had actually been straightened (eliminated) by the Indonesian side in the history of Indonesia-centrist. And on the other hand, things are curling history that relating to fraudulent acts, terror and human rights violations are prosecuted by the Papua to remain listed as part of the history of Papua.(Note 32) Spiral historiography of Indonesia-centrist repeated. Irian was seized at the time of the President Soekarno; and Papua broken by President Megawati. While Soekarno-willed upon unity Sabang Merauke, Megawati act in the context of preserving the integrity of Papuan political struggle.

Political regional expansion or it could be called internal separatism, become a major policy versus politics in solving the self-liberation struggle in conflict zones vertically. There is also a political hidden soldiery to strengthen its dominance of the local political dynamics through the territorial commands and folding number of soldiers and weaponry. Politics wich are constantly being developed, although it is also recognized, has failed to deliver prosperity.

Internal separatism has also been practiced in Aceh based on racism, namely disintegration and ethnic provokes, raising militias, and continues to the formation of new provinces. In the context of Papua who are struggling, internal separatism as a political policy is a necessity when viewed from the side of Indonesia. For Indonesia, beyond the considerations is of political considerations geo-culture of Papua. Even granting the status of special autonomy for Papua, also on the basis of political considerations, without considering the locus privilege Papua as customary land.

As a result, the political division was not in accordance with the cultural picture of Papua. If viewed from the side of conflict resolution, internal separatist conflict only transform vertical to horizontal, or of manifest in to latent. Conversely, when the awareness to Papua's actually increased with the implementation of the policy of internal separatism, will be the addition of new energy into the spirit vertical conflict.

History is extremely important, said Ibn Khaldun (1332 AD-1406 AD), because, history invited to understand the origin of the creature (the Papuans), how the situation and the conditions that make them switch from one hand of power to the power of another, or from being a colony into a new colony to another. However, if the history of Papua reconstructed just a straight, in the sense of eliminating the policy and political action kinky-curly from the colonial, of course, it would be misleading for generations in defining what and who they were. Moreover, politically, the writing of historiography Indonesia-centrist in dealing with Papua has been absolutized.

Then the remaining effort is on the political courage of Papua historians to rewrite so it curls into a large book of historiography Papua-centrist. The nature of Papua-centrist explains the conditions and situations based on geoculture in Papua. This is very useful as a resource for formulating identity of Papua's, in addition to strengthening the privilege locus of Papua. Next is the political demography of Papua can be reconstructed, "The Papuans are indigenous children, or who have baptized customarily. The rest are citizens of Papua alone. "Finally, the division of Papua politically was not an issue when it becomes seven provinces, because it is according to the geo-cultural hemisphere of Papua alone.

In that regard Otto Syamsuddin Ishak wrote: 1) From the sorry to panic about Political Conditions in Aceh during DOM (Political conditions in Aceh Province during military operations), 1989-1998; 2) Bung Karno: a mouthpiece for the people of Indonesia (Sukarno's set of Speech); 3) Knitting peace in Maluku; examines religious conflicts from 1999 to 2000 on the political situation (Political conditions in Maluku Province since 1999-2000) and so on.

A key issue is that the Papua not appear physically alone (eg. Melanesian curly -vis Malay not curly) but a habit (custom) cultural, ideological and philosophical, are different. The Malays know the pattern of kinship "bilateral" or "non-unilineal" within the meaning of the origin of both biological parents get recognition in the affiliate while in Papua applicable is the dominant system of "uni-lineal" as in Melanesia in general a very adrift in the paternal line or patrilineal. In that regard for example an attempt to apply the concept of "equal distribution of poverty" which is now known as the "Raskin" (rice to the poor), and various subsidies poverty line with, among others, the cultural line up groceries and the other is completely against the nature of identity and humanity of PapuaMelanesia were varied in four distribution patterns of economics, has been described above.

Again, the view of Papua as occupied apparently not included in the category of peripheral or marginal line in Indonesia because the system does not Indonesian. Papua-Indonesian or otherwise Papua because both of them can only be united in a process called "integration". Thus it should failed also what is called or autopia as 
"separatism" and even "treason" after humiliation term "Irian" which has now replaced by the glorification term of "Papua".

For us both are different sides virtually upstream and estuaries despite a fertilizer and herbs from the same sources. Papua in Indonesia means integration or Papua outside Indonesia means independent. Indonesia and Papua not otherwise remained an eternal futurity within range of each other in the immortality never knitted and that no doubt denied anyway.

\subsubsection{King in Morning Star Rising?}

King in the article entitled Morning Star Rising?, had started with words: "Indonesia Raya and The New Papuan Nationalism" about the author and the Constitution of 1999 stated:

The official bureaucracy has long been home to secret or not-so-secret OPM supporters and other patriotic "secessionists," including the author (Don Flassy), one of the Presidium leaders destined to be arrested in November 2000.

Again according to King:

8/96-24 As a senior civil servant on the provincial development planning board, the author was able to help "validate" the occupation of the Irian Jaya Arts Center building in Jayapura by the Presidium's militia (Satgas Papua: Satuan Tugas Papua, Papua Taskforce) and its officially sponsored ex-OPM veterans, until a police crackdown in December 2000 ended that occupation.

[(15/103-41 Some have suggested that civil servants take on a greater role in the movement, but that proposal is complicated by the taint of collaboration attaching to anyone in straightforward government service. At the same time, the Dewan Papua platform recommends that the proportion of Papuans in senior civil service positions be drastically increased, and indeed by 2001 all bupati (regency heads) save one were ethnic Papuans. There is a good deal of informal coordination and mutual support between the Presidium leadership and established Papuan bureaucratic statesmen with ties to Jakarta, such as Bas Suebu, currently (at that time) Indonesia's Ambassador to Mexico. These contacts are tolerated by the central government. On the other hand, a top-secret strategy document originating in the militarydominated Ministry of Internal Affairs and dated June 8, 2000 (that is, only days after Congress Papua II concluded) called for Papuan officialdom to be cleansed of pro-independence figures and actually named Don Flassy, then still serving at the provincial development agency, Bappeda.

Further,

[(21/109-64 "The constitution of the 'State of Papua' as was envisaged in Jayapura" by the Agence France Presse, January 6, 2000. The document certainly originated with the prolific and proactive constitution drafter and Presidium member, Don the author, who was arrested in 1998 for setting up a Papuan Independence Committee which attracted Theys Eluay's endorsement. The author proceeded in 1999 and early 2000 to issue a stream of documents in both Indonesian and English under the auspices of this committee and Eluay's tribal council, including proposals about a "transitional" (sometimes "provisional") government for Papua, which implied some form of consent from Indonesia. These documents or their kin circulated at both Mubes and Kongres, but were never formally adopted, interviewing the author, in Jayapura, August 16, 2001. See documents composed by the author, including "The Papuan Transitional Government," proposed by the Papuan Independent (sic) Committee and supervised by the Papuan Customary Council, Sentani (February 1999), and "Basic Guidelines for the State of Papua," Port Numbay (March 2000). Flassy's proposed currency was a Papuan guilder, not the Dutch guilder"

A recognition of the supporters of Don Flassy to be realized transition Government on July 1, in preparation for the announcement of independence on December 1, 2000 but not taken (an interview of King with Franzalbert Joku, Sydney, June 8, 2000).

Theys and the other members of the Presidium also arrested are General Secretary, Thaha Al-Hamid, moderator Pastor GKI Herman Awom, and Don Flassy from BAPPEDA, and the leader of tapol/napol John Mambor.

\subsubsection{Sinar Harapan: Morning Star Fluttering, Special Autonomy Held}

On December 1, 1999morning, Jayapura become a ghost town. School children, office workers even instructed entrance; still they took the afternoon off. Shops were closed and the streets were deserted. Looks were several cars and buses that transport the masses towards Taman Imbi. Since dawn, people of Papua have started walking toward the heart of the town. 
At that time, the SP (Suara Pembaruan) down the street from Waena to the Taman Imbi, see how they are clustered walk while singing into town with a distance of 30 kilo meters, it seems they were not tired.

That day, the sun covered with clouds. Since dawn, the drizzle flushed the city of Jayapura. After all, the cold is not a barrier. In the city center, in front of Taman Imbi standing monument Yos Sudarso, about 5,000 people had gathered since the previous night. Filep Karma when it was just wearing a piece of cloth with decorative of Morning Star.

Although he seemed to shiver, spirit of independence figures beat the cold. In the stands, appear Theys Eluay, Don A.L Flassy, Rev. Herman Awom, Taha Alhamid, John Mambor, Melcky Mandosir, Bas Yufuway, and a number of other figures.

At 06.00 EIT, Don Flassy was screaming hysterically. His hands ware took up. "Merdeka ......Medeka (Freedom ... freedom). Thank you Jesus, thank you Jesus," he repeated. At that time, the Morning Star flag is being flown by three youths Papua, Papua tune Hai Tanaku Papua (Hi my land Papua). The flag was hoisted on a pole height of about seven meters alongside the Dwi Warna (Red White) flag first flown.

Suddenly, like a chorus, the sound of crying came from the mouths of thousands of people waving accompany the Morning Star. That day, indeed was solemn ceremony with full emotional.

Since waving Morning Star until now, the long journey to Papua to not be separated from the Unitary Republic of Indonesia (NKRI) is full of twists, like a drama play. Special Autonomy (Otsus), is the ending of all the demands of the word M (Merdeka). That is the letter which is often mentioned and heard to this day.

Otsus held in 2001 in response to the Morning Star fluttering December 1, 1999, has been assumed to be only limited money. Police too busy catching the people who fly the Morning Star flag. Law enforcement officials in Papua among police, prosecutors, the Financial Supervisory Agency (BPKP), the Supreme Audit Agency (BPK), the Corruption Eradication Commission (KPK) is very rare, never even want to bother with criminals who spend tens of billions of rupiah of Otsus funds.

In fact, corruption continues reigning, development is not on the road, the heart of the people injured and screaming. Can with voice, can read, can also with symbols of disagree. If honest, now there is special autonomy as for the Morning Star flag. "Do not lie. Special Autonomy is the biological child of the Morning Star flag. Because of the Morning Star flag fluttering, there is a new special autonomy", said Secretary General of the Papua Presidium Council (PDP) Taha Alhamid. That is the reality. "We wait for law enforcement want to make what with the corrupt that spend money of special autonomy in Papua. As long as there is no rule of law, meant to be expected of law enforcement officers participated maintains abuses within the framework of special autonomy devastating and crippling", he said.

Governor most responsible, because the governor is to know what should be done within the framework of special autonomy. Seven years is the people's view, there was no change. So, is it wrong when people shout, "Did the police busy to catch people's, because the flag and do not know what is behind the flag. This is essential. Who separatists and who want to destroy this country", he said. See the special autonomy that has been lying, should be autonomous cases. As if the government has no steps and no way out and do not see any other option how to save autonomy.

\subsection{Politiecs Negotiation}

Do not forget, special autonomy status is a political negotiation. If it is defeated, it means that the political negotiations also failed. This people of Papua to build a political negotiation with the Government of the Republic of Indonesia and the government destroy.

According to Taha Alhamid Secretary General of the PDP, "Evaluation or renegotiation or revised is the authority of the government and the legislature. That's the record, according to the Special Autonomy Law any change must be consulted with the people of Papua".

He no longer wants to talk about the special autonomy, because of the past until today, same thing. "We do this as if talking to a wall, not by human conscience. President Susilo Bambang Yudhoyono (SBY) and Vice President Muhammad Jusuf Kalla should take responsibility and prove their commitment to the implementation of special autonomy in Papua," he said.

Their promise to the people through the special autonomy that has been running for seven years, until now have not provided adequate changes. In fact, Otsus is a political solution. 
Although the central government often claimed to have given such great authority, including the so great funds, remain nothing could happened. Indonesia is a unitary state so there is no central or regional. That is, governments in the region, is representative of the central government. That is, the Governor Barnabas Suebu it is SBY in Papua or Abraham Atururi is SBY in West Papua.

"So, do not talk about local or central government, but the government is because the name of the government that is one," he said.

Researchers from the Indonesian Institute of Sciences (LIPI) Muridan Widjojo revealed, it makes sense, to dampen the raising of the Morning Star flag, was given special autonomy as its answer.

"Autonomy is born because the demands for independence. Papuans demanded independence because of injustice. So, the long flow indeed. When people say the birth of special autonomy as the Morning Star and the demand for independence, that's for sure", he said.

Chairman of the Papuan Customary Council, ForkorusYaboisembut said the fundamental problem that has been animating for special autonomy and ingrained for Papuans. "So, if you want to be released in a short time, impossible. That there is a murder", he said.

Otsus not resolve the matter. "It is precisely this problem that must be solved. Otsus was granted, because of political problems," he said.

He likened the bird in a cage to be fed good, sleep good, no wet by rain. However, if flying, it will hit here and there. "That means there is something less wrong. The cause is there. Even though Indonesia gave money to billions of rupiah, but a bird in a cage is remain to move on. This matter should be resolved and should be addressed by special autonomy, "he said. [SP/Roberth Isidorus Vanwi]

\section{End Remark}

Thus, if since in 2005 there was the dream state with the name Republic BBM in Indonesia, starting in 1999 there was a Constitution of a dream state at least once. State of West Papua which was dreamed would happen although exchanged with Special Autonomy. In the history of ethical effort embodied in the Constitution of Republic of Indonesia Year 2001 The tub is also a dream in a sense continues to be disturbed so that is also ending in a dream may not be delivered.

Prophet of Papua, Pastor I.S. Kijne on the first page of the book Kota Emas (Gold City), ITU DIA Volume IV, 1954 wrote: "Jang dimimpi walau tak akan djadi, pasti abadi (Though in a dream that not would be, certainly immortal)." Thus, definitely the Papuans with its brother/sister of the Indonesian nation are in the aroma and atmosphere of a dream presented by the system that calls itself, and we know also the name of that is the "Pemerintah Indonesia (Indonesian Government)".

There is a small number of people (politicians, bureaucrats, statesmen) who wishes, just and would not even know the brothers/sisters of Papua and also not of brothers/sisters of Indonesia wanting this or not, does not matter them at all. As well as disaster of Lapindo Mud where people are forced to say "syukur (grateful)," the sale of gas and gold are not means at all stop. In Papua, the Papuan and Indonesian people are, surely yes, "syukur (grateful)". And it is fragments of necessity borne, however in dreams only. This is means to change attitude and full respect towards people's benefit as citizen.

Let's realize the dream to build dream states. Indonesian nation and the nation of Papua each have their own country, and there is also toward the common goal, which is bilateralism, if possible, although Indonesia in its Constitution does not specify about the border from where to where they settled the globe.

Indeed the Constitution 1999 (of dream) on KRP-3 has gained the honor of becoming a real Papuan People's Constitution, called the Constitution of 1999 preceded the UDI (Unilateral Declaration of Independence) of Papuan Nation and NRFPB in October 19, 2011 as the facto.

However, for the togetherness of Papua and Indonesia in the form of integration it is ensured a clash if we understand clearly each constitution, the 1999 Papua Constitution versus the 1945 Indonesian Constitution. With the opposite binary method of Levi Straus' Structuralism (1964) the measurement of Papua remains within Indonesia and Papua outside Indonesia are shown in the following Table: 
Table 1. Papua inside Indonesia versus Papua outside Indonesia, Flassy, (2017).

\begin{tabular}{|c|c|c|}
\hline Domain & Papua inside Indonesia & Papua outside Indonesia \\
\hline Papuan identity & $\begin{array}{l}\text { declared in the Bhineka's, ireal } \\
\text { and measurable }\end{array}$ & maintained. \\
\hline Mentality & $\begin{array}{l}\text { dishonest, CCN, Liquid, Drugs, } \\
\text { HIV / Aid, individualistic. }\end{array}$ & $\begin{array}{l}\text { honest, healthy mentality, communal (nostalgic } \\
\text { edenic). }\end{array}$ \\
\hline Reality & not visible, pretend. & Visible, realistic, plain. \\
\hline Population & $\begin{array}{l}\text { tends to be extinct }(700,000 \text { out of } \\
3,000,000) \text {. }\end{array}$ & an opportunity to increase (1958 800,000 souls, \\
\hline $\begin{array}{l}\text { Endemic Flora and } \\
\text { Fauna } \\
\text { etc. }\end{array}$ & contaminated and extinct. & gaining chance to be protected. \\
\hline
\end{tabular}

\section{References}

Abdulgani, R. H. (1964). Dari Sabang Sampai Merauke: Satu Nusa, Satu Bangsa (From Sabang to Merauke: One Archipelago, One Nation)!Penerbitan Chusus 313. Djakarta: Departemen Penerangan R.I.

Aditjondro, G.J.(1993). Penggelapan Nasionalisme Orang Papua dalam Historiografi Indonesia (Darkening of Nationalism of Papuans in Indonesian Historiography), Salatiga, Seminar Papers.

Antoh, D. (1977). Rekonstruksi \& Transformasi Nasionalisme Papua (Papua Nationalism Reconstruction \& Transformation), Jakarta, Sinar Harapan.

Asad, T. (2004). Where Are the Margins of the State?In Veena Das and Deborah Poole (eds), Anthropology in the Margins of the State, pp. 279-288. Santa Fe and Oxford: School of American Research Press and James Currey.

Ballard, C. F. C. (2009). The Art of Encounter: Verisimilitude in the imaginary exploration of interior New Guinea, 1863-1876. In Margaret Jolly, Serge Tcherkézoff and Darrell Tryon (eds), Oceanic Encounters. Honolulu: University of Hawaii Press. https://doi.org/10.22459/OE.07.2009.08

Broek, T. van den, \& Alexandra, S. (2001).Raising the Morning Star: Six Months in the Developing Independence Movement in West Papua.Journal of Pacific History, 36(1), 77-92. https://doi.org/10.1080/00223340123100

Bruggen Casper, (2011). 'Verge(e)t ons niet' Het Papoea Vrijwilligers Korps (1961-1963), Aspek Amsterdam 2010-2011, Leger Museum Nederland.

Cahya, P. (2009). History of the story of the integration of Papua into Indonesia The experiences of the Kaimana people in the days of Trikora and Pepera Trikora dan Pepera," in, 104Paramita, 25(1), January 2015.

Das, V. (2004). The Signature of the State', in, Veena Das and Deborah Poole (eds), Anthropology in the Margins of the State, pp. 225-252. Santa Fe \& Oxford: School of American Research Press and James Currey.

Djopari, J. R. G. (1993). Pemberontakan Organisasi Papua Merdeka (Rebellion of Free Papua Organization), Jakarta: Grasindo Gramedia Widiasarana.

Djuyoto, S. (2007). Tahun 2015 Indonesia "Pecah" (In 2015 Indonesia will "broken"), Jakarta, Pustaka Perdamaian.

Dumupa, Y. F. (2006). Berburu Keadilan di Papua: Mengungkap Dosa-dosa Politik Indonesia di Papua Barat (Hunting Justice in Papua: Revealing Indonesia's Political Sin in West Papua). With a foreword by Johnson Penjaitan. Yogyakarta: Pilar Media.

Duncan, C. R. (2004). From Development to Empowerment: Changing Indonesian Government Policies toward Indigenous Minorities. dalam Christopher R. Duncan (ed.), Civilizing the Margins: Southeast Asian Government Policies for the Development of Minorities, pp. 86-115. Ithaca: Cornell Uni. Press.

Flannery, T. (2000). Throwim Way Leg: Tree-Kangaroos, Possums and Penis Gourds: On the Track of Unknown Mammals in Wildest New Guinea. Berkeley, CA: Grove Press.

Flassy, D. A. L. (1991). Struktur Sosial di Wilayah Bahasa dan Budaya Toror Bagian Barat dan Tengah Doberai Irian Jaya: sebuah Sketsa Struktur Sosial di Nieuw Guinea (Social Structure in Toror Language and Culture Areas the Western and Central Doberai Irian Jaya: a Sketch of Social Structures in New Guinea). MA Thesis, Leiden University. 
Flassy, D. A. L. (1999). Basic Guidelines State of West Papua. Port Numbay (Jayapura): The Independent Committee West Papua, Unpublished manuscript.

Flassy, D. A. L. (2001). Rendes Vous dengan Perjuangan Kemerdekaan Papua Barat (Rendez Vous with the West Papua Independence Struggle), Unpublished manuscript held in collection of author.

Flassy, D. A. L. (2004). Sinkronisasi UU-RI No. 21/2001 versus UU-RI No. 45/1999: Tegakkan Wibawa dan Wujudkan Kedamaian di 7 Wilayah Satuan Adat Papua; Acang Alternatif: 7 Provinsi, 1 Kota Ibu Kota Khusus, 3 Kota Transito, Menteri Khusus Urusan Papua; Sebuah Pencerahan (Synchronization of RI- Law No. 21/2001 versus RI -LawNo. 45/1999: Enforce Authority and Realize Peace in 7 Papua Customary Unit Areas; Alternative: 7 Provinces, 1 Special Capital City, 3 Transito Cities, Special Ministers for Papua Affairs; An enlightenment), With a foreword by D. Asmuruf. Jayapura.

Flassy, D. A. L. (2005). Tri Ganda Logika (Triplefold Logic) Papua-Melanesia: Filsafat Dasar Konstitusi Negara Kebangsaan Konfederasi Papua (Triple fold Logic Papua-Melanesia: Basic Philosophy and the Constitution of the Confederation Nation of Papua)'. Unpublished manuscript held in collection of author.

Flassy, D. A. L. (2013). Aspek dan Prospek Seni Budaya Papua (Aspects and Prospects of Papuan Cultural Arts), Jakarta, Balai Pustaka.

Garson, J. G. M. D., \& Charles, H. R. F. S. A. (1892). Notes and Queries on Anthropology. Royal Anthropolgy Institute of Great Britain.

Geertz, C. (1973). Interpretation of Cultures: Selected Essays.

Geertz, C. (1983). Local Knowledge: Further Essays in Interpretive Anthropology.

Geertz, C. (1988). Works and Lives: The Anthropologist as Author).

Geertz, C. (1995). After the Fact: Two Countries, Four Decades, One Anthropologist.

Geertz, C. (2000). Available Light; Anthropological Reflections on Philosophical Topics.

Giay, B. (2000). Menuju Papua Baru: Beberapa Pokok Pikiran Sekitar Emansipasi Orang Papua (Towards a New Papua: Some Principles of Mind Around the Emancipation of the Papuans). Waena: Deyai.

Government of Netherlands New Guinea, (1961), Report On Netherlands New Guinea For The Year 1961, Presented to the Secretary General of the United Nations pursuant to Article 73(e) of the Charter. The Hague: Ministry of Home Affairs and Ministry of Foreign Affairs.

Human Rights Watch. (2000). Indonesia: Human Rights and Pro-Independence Actions in Papua, 1999-2000. A Human Rights Watch Short Report, 12(2), May.

Human Rights Watch. (2000). Retrieved June 30, 2007, fromhttp://www.hrw.org/reports/ 2000/papua/. Last consulted, 30 .

Human Rights Watch. (2001). Violence and Political Impasse in Papua. Retrieved 30 June 2007, from http://www.hrw.org/reports/2001/papua/PAPUA0701.pdf

ICG (International Crisis Group). (2003). Dividing Papua: How Not To Do It'. Asia Briefing No. 24, 9 April 2003. Jakarta and Brussels: International Crisis Group. Retrieved 5 May 2005, from http://www.crisisgroup.org

Josselin, de Jong, J. P. B. (1977). The Malay archipelago as a field of ethnological study'. In P.E. de Josselin de Jong (ed.), Structural Anthropology in the Netherlands: A Reader, pp. 166-182. KITLV Translation Series No. 717. The Hague: Martinus Nijhoff.

King, P. (2004). West Papua and Indonesia since Suharto: Independence, autonomy or chaos? Sydney: University of New South Wales Press.

KIP (Komite Independent Papua). (1999). Pulau Fajar Ke-emas-an, Sebuah Tawaran Kerjasama Multilateral (Island of Golden Dawning, An Offer of Multilateral Cooperation), Unpublished manuscript.

Kjar, R. (2002).The Invisible Aristocrat: Benny Giay in Papuan History, BA (Hons) Thesis, Faculty of Asian Studies, Australian National University, Canberra. Retrieved August 29, 2007, from http://www.papuaweb.org/dlib/s123/kjar/_ba.html

Lévi-Strauss, C. (1964). The Story of Asdiwal in Edmund Leach, ed.

Lévi-Strauss, C. (1964). The Structural Study of Myth and Totemism, Tavistock Pub.

Lewis, A. (1966). (Nobel Prise Winner). Peasants and Dualism with or without Surplus Labor, dalam AK Sen. The Journal of Political Economy, U Chicago Press. 
Lewis, C. (1934). The Decline of American Capitalism, New York, Covici Friede Publishers.

Lubis, M.(1984). Etnik, Elite dan Integrasi Nasional: Minangkabau 1945-1984 Republik, Gre Publishing.

Melissa, L. (1994). Rainforest Relation: Geneder and resource use among the Mende of Gola, Sierra Leone, Smithsonian Institution Press, Washington, D.C.

Miedema, J., Cecilia, O., \& Rien, A. C. D. (1998). 'Preface'. In Jelle Miedema, Cecilia Ode, and Rien A.C. Dam (eds), Perspectives on the Bird's Head of Irian Jaya, Indonesia: proceedings of the conference, Leiden, 1317 October 1997, pp. ix-xiii. Amsterdam: Editions Rodopi.

Mohammad, H. (1928). Indonesia Vrije (Indonesia Merdeka) sebagai pleidoi di depan pengadilan Belanda di Den Haag.

Muller, K. (1991). Irian Jaya, Nieuw-Guinea, Singapore, Periplus Editions, Inc.

Narakoby, B. (1980). The Melanesian way, Institute of Papua New Guinea Studies.

Naroll, R. (1964). "On'Ethnicunit Classification" dalam Cultural Antropology.

Ondawame, O. (2001). "One People, One Soul": West Papuan Nationalism and the Organisasi Papua Merdeka (OPM)/Free Papua Movement. PhD Dissertation, The ANU.

Oosterwal, G. (1962). De Papoea,zijn ook mensen als wij, s'Gravenhage,Vanhoeve.

Oram, N. D. (1972). 'Samarai'. In Encyclopaedia of Papua and New Guinea, pp. 1028-1029. Carlton, Victoria: Melbourne Uni. Press in association with the UPN.

Ottow, J. C. G., \& Helga, O. (2004). Im Namen Gottes betreten wir dieses Land. Münster: LIT Verlag.

Paijmans, K.(1976). New Guinea Vegetation, Canberra, National University Press.

Parson, T. (1949).The Structure of social Action. Glencoes, 1llinois, The Free Press.

Pemda, Tk. I. I. J., \& Biro, P. D. (1993). Peranan Lembaga Adat Irian Jaya (The Role of Irian Jaya Customary Institutions), Unpublished manuscript.

Pemerintah Provinsi Irian Jaya. (2001). Pola Dasar Pembangunan Daerah (Basic Patterns of Regional Development Program) Provinsi Irian Jaya Tahun 2000/2001-2004/2005, Jayapura.

Pemerintah Provinsi Irian Jaya. (2001). Program Pembangunan Daerah - PROPEDA (Regional Development Program) Provinsi Papua Tahun 2000/2001-2004/2005, Jayapura.

Pemerintah Republik Indonesia. (2000). Garis-Garis Besar Haluan Negara (GBHN) tahun 2000 Tap MPR No.II/MPR/2000, Jakarta.

Pike, K. L. (1967). Language in relation to a unified theory of the structure of human behavior. The Hague-Paris: Mouton. https://doi.org/10.1515/9783111657158

Ranis, G. dan J. C. F. (1961). A theory of economic development. American Economic Review. 1961 Sep., 51(4), 533-565.

Raweyai, Y. T. (2002). Mengapa Papua Ingin Merdeka (Why Papua Want Freedom), Jayapura: Presidium Dewan Papua.

Sanggenafa, N. (1989). Kepemimpinan Tonowi dalam Penyelesaian Sengketa pada Orang Ekagi (Tonowi's Leadership in Settling Disputes with Ekagi People), Unpublished Paper.

Schoorl, P. (1996). Besturen in Nederlands Nieuw Guinea 1945 1962: ontwikkelings- werk in een periode van politieke onrust. Leiden: KITLV Uitgeverij.

Sharma, A., \& Akhil, G. (2006). eds.The Anthropology of the State: A Reader. Malden, MA: Blackwell Publishing.

Sharma, A., \& Akhil, G. (2006). Introduction: Rethinking Theories of the State in an Age of Globalization. In Aradhana Sharma and Akhil Gupta (eds), The Anthropology of the State: A Reader, pp.1-41.Malden, MA: Blackwell Publishing.

Silzer, P. J., \& Heljä, H. eds. (1984). Index of Irian Jaya languages, Summer Institute of Linguistics.

Soekarno. (1933). Menuju Indonesia Merdeka (Towards Freedom Indonesia).

Soekarno. (1954). Di Bawah Bendera Revolusi (Under the flag of revolution), Gunung Agung, Jakarta.

Soekarno. (2001). Indonesia menggugat: Pidato pembelaan Bung Karno di muka hakim kolonial (Indonesia sued: Speech in defence of Bung Karno in front of colonial judges), Yayasan Untuk Indonesia. 
Stott David Adam (2011). Would An Independent West Papua Be A Failing State? The Asia-Pacific Journal: Japan Focus. Retrieved from http://japan focus.org/-David_Adam-Stott/3597/article.html

Subandrio. (2000). Meluruskan sejarah perjuangan Irian Barat (Straighten the history of the struggle of West Irian), Jakarta, Yayasan Kepada Bangsuku.

Sumule, A. (2003a). Swimming Against the Current: The Drafting of the Special Autonomy Bill for the Province of Papua and its Passage through the National Parliament of Indonesia. Journal of Pacific History, 38(3), 353369. https://doi.org/10.1080/0022334032000154083

Sumule, A. (2003b). Mencari Jalan Tengah: Otonomi Khusus Provinsi Papua (Looking for a Middle Path: Special Autonomy for the Papua Province), Jakarta: Gramedia Pustaka Utama.

Syamsuddin, O. I. (2000). Bung Karno: penyambung lidah rakyat Indonesia Kumpulan Pidato Sukarno (Bung Karno: Indonesian people's tongue spokesman Sukarno's Speech Collection).

Syamsuddin, O. I. (2000). Dari maaf ke panik tentang Kondisi Politik di Aceh semasa DOM 1989-1998 (Political conditions in Aceh Province during military operations).

Syamsuddin, O. I. (2000). Merajut damai di Maluku : telaah konflik antar umat 1999-2000 tentang kondisi politik sejak 1999-2000 (Political conditions in Maluku Province since 1999-2000).

Tambunan, H. (1992). Potensi Sumberdaya Mineral Kabupaten di Irian Jaya (District's Potential Mineral Resources in Irian Jaya). Jayapura, KANWIL Dep. Pertambangan dan Energi Provinsi Irian Jaya.

Tan, M. (1925). Naar de Republiek Indonesia (Menuju Republik Indonesia/Towars the Republick of Indonesia).

The Liang Gie dan F. Soegeng Istanto. (1966). Pertumbuhan Pemerintahan Propinsi Irian Barat Dan Kemungkinan2 Perkembangan Otonominja Dihari Kemudian (The Growth of the Government of West Irian Province and the Possibility of the Autonomy of Development in the Later Days). Sukarnapura, UNCEN, $\mathrm{mm}$.

Timmer, J. (2000a). The Return of the Kingdom: Agama and the Millennium among the Imyan of Irian Jaya, Indonesia. Ethnohistory, 47(1), 27-63. https://doi.org/10.1215/00141801-47-1-29

Timmer, J. (2000b). Living with Intricate Futures: Order and Confusion in Imyan Worlds, Irian Jaya, Indonesia. $\mathrm{PhD}$ Thesis, University of Nijmegen. Nijmegen: Centre for Pacific and Asian Studies, University of Nijmegen.

Timmer, J. (2003). Narratives of Government and Church among the Imyan of Papua / Irian Jaya, Indonesia. State, Society and Governance in Melanesia Discussion Paper 2003/5. Canberra: State, Society and Governance in Melanesia Project, Research School of Pacific and Asian Studies, The Australian National University. Retrieved 22 November 2004, from http://rspas.anu.edu.au/melanesia

Timmer, J. (2004a). Melanesia in Review: Issues and Events, 2003 - West Papua.The Contemporary Pacific, 17(2), 409-419. https://doi.org/10.1353/cp.2004.0062

Timmer, J. (2004b). Government, Church, and Millenarian Critique in the Imyan Tradition of the Religious (Papua/Irian Jaya, Indonesia). In Holger Jebens (ed.), Cargo, Cult \& Culture Critique, pp. 117-136. Honolulu: University of Hawai'i Press.

Timmer, J. (2005). Melanesia in Review: Issues and Events, 2004 - Papua. The Contemporary Pacific, 16(2), 448456. https://doi.org/10.1353/cp.2005.0073

Timmer, J. (2007). Erring decentralization and elite politics in Papua. In Henk Schulte Nordholt and Gerry van Klinken (eds), Renegotiating Boundaries: Local politics in post-Suharto Indonesia, pp. 459-482. Leiden: KITLV Press. https://doi.org/10.1163/9789004260436_021

Timmer, J. (2009). A Brief Social and Political History of Papua (1962-2004). In Andrew J. Marshall and Bruce M. Beehler (eds), The Ecology of Papua. Hongkong: Periplus Editions.

Timmer, J. (2013). The Threefold Logic of Papua-Melanesia: Constitution-writing in the Margins of the Indonesian Nation-State. Oceania OCT20, Oceania Publications, 83(3), 158-174. http://doi.org/10.1002/ocea.5018

UN. (1969). 24 ${ }^{\text {th }}$ Session of UNGA Provisional A/PV. 1812, 19 November 1969.

Verhave, J. P. dan Henk., \& Voorhoeve, W. A. (2000). Dienst Van Gezondheid Zorg, Wageningen, The Netherlands Society of Tropical Medicine and International Health.

Vlasblom, D. (2004). Papoea: Een geschiedenis, Amsterdam: Mets \& Schilt.

Weiner, J. F. (1988). Mountain Papuans: Hisorical and Compar-ative Perspectives from New Guinea Fringe 
Highlands Societies, Cambridge: Uni.Press. https://doi.org/10.3998/mpub.9552

Wonda, S. (2007). Tenggelamnya Rumpun Melanesia (Thesinking of Melanesian race), Yogyakarta, Galang Press.

Wurm, S.A. (1975).New Guinea Area Languages and Language Study,1:Papuan languages and the NewGuinea Linguistic Scene,Pacific Linguistics, C.38, Canberra: ANU.

Wurm, S.A. (1977). New Guinea area Languages and Language Study, 3: Language, Culture. Society, and the modern world, IPacific Linguistics, C40, Canberra: ANU.

Wurm, S. A. (1982). Papuan Languages of Oceania, ARS Linguistica 7, Stuttgart: Gunter NarrVerlag Tubingen.

Wurm, S. A., \& Shiro, H. (1981). Language Atlas of the Pacific area I: New Guinea area, Oceania, Australia, Stuttgart: Geo Center.

Yacub M, (2007). Ibn Khaldun (1332 M-1406 M), Penggagas Filsafat Sejarah: Kitab al-Ibar/Tarikh Ibn Khaldun (The founder of Historical Philosophy: Kitab al-Ibar / Date of Ibn Khaldun), in Analitica Islamica, 9(2), Jakarta. Yoman.

Yoman, S. S. (2000). Pintu Menuju Papua Merdeka: Perjanjian New York 15 Agustus 1962 dan Pepera 1969 Hanya Sandiwara Politik Amerika, Indonesia, Belanda dan PBB(The Door to Free Papua: New York Agreement August 15, 1962 and 1969 Pepera Act Only Political Plays of American, Indonesia, the Netherlands and the United Nations),

Yos, R. S. (2008). Dia Yang Mahir Dalam Revolusi (He, the advanced one, in the Revolution (on Tan Malaka), Tim Tempo.

\section{Notes}

Note 1. Apparently still not to be understood that, before becoming Indonesia's, Papua has been formed through a phase of integration among the Papua themselves called Papoeanizering (Papuanization) 1828-1949 to 1970so it is not necessarily. Papua in it self is a nation of uniting groups of ethnics and tribes.

Note 2. According to sources the Dutch-PVK-Army (Casper van Bruggen, 2011: 219): Kapten Benny Murdani was bevond tot major terwijl hij zich in de jungle bij Merauke bevond (....was commander rank of captain to major hiding and ran a way from the pursuit, just daring to show himself after squash of weapons announced by UNTEA$\mathrm{UN}$.

Note 3. Triple Fold Logics or two units of three in the sense that there are two parts, each consisting of 3, namely 3 Principles of Melanesian Brotherhood (one people-one soul-one solidarity) and 3 Principles of Papuan Virtue (mercy-faithful-honest).

Note 4. Although for that shake, Drs. Agus Alua, MA, head of the team trying to answer this rhetorical of Habibie in June of that year through a Working Paper entitled "Already, We Reflect" is a futile effort because not responded by Indonesia.

Note 5. Cahya Pamungkas, 2009, History of the story of the integration of Papua into Indonesia The experiences of the Kaimana people in the days of Trikora and Pepera" in 104Paramita Vol. 25, No. 1 - January 2015.

Note 6.The UN 24 ${ }^{\text {th }}$ Session of UNGA: Provisional A/PV. 1812, 19 November 1969).

Note 7. This phenomenon would occur repeated almost every year on May 1; There are two celebrations that of the Government with the claim "The day return of West Irian (Papua) to the bosom of Mother Pertiwi Earth with a period ends the Provisional Government of the UN/UNTEA, being by the Papua People claimed as time began "occupation" of the Tanah Papua is then legitimized by World (UN) on the Act of Free Choice in August 1969 very detrimental to the People Nation of Papua received onNovember 19, 1969 (above).

Note 8 . Indeed somewhat exaggerated but is an ambition on the basis of the moral order that is charged for the sake of the constitution itself.

Note 9. In order to promote RI Law No.45 Year 1999 on Expansion of province into three provinces with theRI Law No. 21 Year 2001 on Special Autonomy for Papua Province.

Note 10. Discuss Pike (1967).

Note 11. As for the State of Indonesia is not an Islamic State so of Papua it is not a Christian State because both are the National State. 
Note 12. Already various occasions meetings with various groups Officials of the State of Indonesia, Komite Independent (Papua Independent Committee) seeks to attract to handle this offer, but as it is said Benny Giay in a seminar in joke that "talks with officials of Indonesia looks like we talk to rock, so there would be no answer or cross talk". Is this correct, I am personally not convinced that, because Abdurrahman Wahid can do spectacular.

Note 13. Need also noted in this regard that New Guinea (Papua) according to Batavia Declaration 7 March 1910 being excluded which nolonger part of Dutch Indies which devotes particular attention to the so-called "Outer Islands," and the forces that Batavia saw at work in this periphery; uploaded June 2016 from https://www.jstor.org/stable/20072201?seq=1\#page_scan_tab_contents

Note 14. The title " Putra Sang Fajar (Son of the Dawn)" was once appointed by playwright Sadono be held by title of colossal drama plaid by Garuda Patria group in Yogyakarta in commemorating 100 days of Sukarno's death; the author include as one cast of the drama that was held in the Balai Batik Alon-alon Utara Keraton Yogyakarta.

Note 15. Genesis, 1.

Note 16. Nieuw Guinea Instituut 1956 : 7-16.

Note 17. Al Gore, 1992: 199-376.

Note 18. Spirit of One Solidarity (Solus Solidarita) representing of complement job of KIP inspired focuses by the Leader of Papua, Theys Hiyo Eluay about Nation of Papua which manner peaceful and will esteem, also if only One People-One Soul hence which is gone to by Totalitarian State whereas which we crave the Federation.

Note 19. No interactive terms are used because of the positive view applied; meaning rejecting or tightening characteristics is not considered. This is the real road to wards liberal-democracy, rather than class conflict, symbolized by "re-cycle" nodes.

Note 20. Taclot Parson, 1951: 205-7, 250, 272-7.

Note 21. Don AL. Flassy, $1983: 136$.

Note 22. Don A.L. Flassy, 1995: -idem-.

Note 24. See Gouvernements-blad 1961/68 and Gouvernements-blad 1961/70 attached.

Note 24. C. Budiarjo \& L.S. Liong, 1988, "West Papua: The Obliteration of a People"; Veur, Paul van der, 1963, Political Awakening in West New Guinea, Pacific Affairs, 36(1), pp 54-73.

Note 25. See Gouvernements-blad 1961/70.

Note 26. Comparing to Japan by its Meji Restoration and Decision to groan Pearl Harbour and fight with USA in creating peace later.

Note 27. This State Device is by the time not getting authentication yet because representing product to end later before the Independence of The State of Papua which is made a promise will be existed by the year 1970 .

Note 28. See Timmer (forth coming) to a common view will be social and economic development in Papua from the early 1960s until 2004.

Note 29. This design was also used for building a such Panthéon in Paris dedicated to the heroes (heroes and heroines) of the nation.

Note 30. Theory of Economic Development.

- John Fei and Gustav Ranis in "A Theory of Economic Development" examine the transition process which is expected to pass an underdeveloped country to move from a state of stagnation towards self growth.

- It is a refinement of the Lewis theory of the unlimited supply of labour.

- Theory Fei-Ranis: A country that excess labour and resource poor economies, most of the population engaged in the agricultural sector in the midst of great unemployment and a high rate of population growth. Agricultural economy stagnates. There are industrial sectors active and dynamic. Development consists of reallocation of labour surplus agricultural contribution to output zero, to the industry where they become productive with equal pay.

- Assumptions used:

(1) Economic two-face divided into traditional agricultural sector stagnant and active industrial sector,

(2) The output of the agricultural sector is a function of land and labour only,

(3) in the agricultural sector there is no accumulation of capital, unless reclaimed,

(4) supply of land is fixed, 
(5) agricultural activities characterized by results (returns to scale), which remains with the labours as variable factors,

(6) the marginal productivity of labour is zero,

(7) output of the industrial sector is a function of capital and labour only,

(8) the population growth as exogenous phenomenon,

(9) real wages in the agricultural sector is considered to be fixed and is equal to the level of real income of the agricultural sector,

(10) workers in each sector only to consume agricultural products.

Note 31.Theory Arthur Lewis, its discussion is in the process of development between urban and rural areas, followed by the process of urbanization between both places. In addition to this theory also review the investment model and the system of wage determination in the modern system also affects the existing urbanization. Lewis assumes that the economy of a country is basically divided into two. In (2014, Imam's Blog, http://imamsyaifuddin.blogspot.com/2014/03/teori-pembangunan-fei-ranis-rostow-dan.html) (1) Traditional economy, it is assumed that rural areas with traditional economy experiencing labour surplus. The surplus is closely related to the main base of the traditional economy. The condition of society in a state of subsistence as a result of the subsistence of economy also marked the value of the marginal product of labour is zero. This indicates that the addition of labour would reduce total production there, contrary to reduce the workforce it does not reduce the total existing production. Thus, real wages are determined by the average value of the marginal product, and not the marginal product of labour itself. (2) The economy of the industry, the industrial sector plays an important role in this sector and also located in urban areas. In this sector it is shows that the very high level of productivity, including inputs and labour used. Especially the marginal value of labour is positive thus the urban area is a destination for job seekers from rural areas. If this happens then labour in industrial sectors will be followed by an increase of output produced. Thus, the urban industry still provides jobs for villagers. In addition to employment opportunities available no less attractive wage levels in the city reached $30 \%$, and this then becomes of interest to the villagers in doing urbanization.

Note 32. That history gives the power of intuition and inspiration to philosophy, while philosophy offers the power of logic to history. By doing so, a historian will be able to obtain valid results relative history of the research process, the basic logic of critical.

\section{Copyrights}

Copyright for this article is retained by the author(s), with first publication rights granted to the journal.

This is an open-access article distributed under the terms and conditions of the Creative Commons Attribution license (http://creativecommons.org/licenses/by/4.0/). 